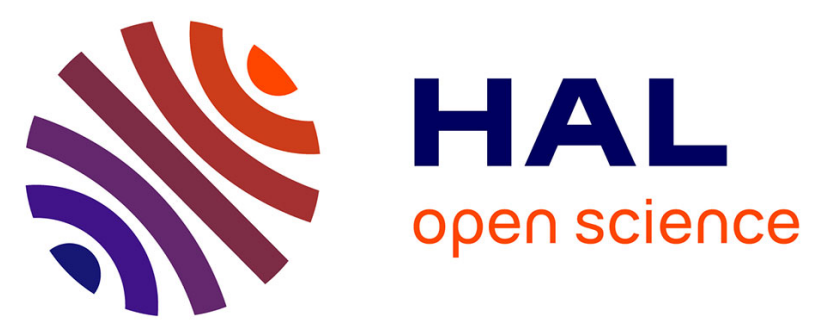

\title{
Adsorption of strontium and caesium onto an Na-illite and Na-illite/Na-smectite mixtures: Implementation and application of a multi-site ion-exchange model
}

Brice Siroux, Aubéry Wissocq, Catherine Beaucaire, Christelle Latrille, Cristina Petcut, Jordan Calvaire, Michel Tabarant, Marc F. Benedetti, Pascal E. Reiller

\section{To cite this version:}

Brice Siroux, Aubéry Wissocq, Catherine Beaucaire, Christelle Latrille, Cristina Petcut, et al.. Adsorption of strontium and caesium onto an Na-illite and Na-illite/Na-smectite mixtures: Implementation and application of a multi-site ion-exchange model. Applied Geochemistry, 2018, 99, pp.65-74. 10.1016/j.apgeochem.2018.10.024 . cea-02285768

\section{HAL Id: cea-02285768 https://hal-cea.archives-ouvertes.fr/cea-02285768}

Submitted on 13 Sep 2019

HAL is a multi-disciplinary open access archive for the deposit and dissemination of scientific research documents, whether they are published or not. The documents may come from teaching and research institutions in France or abroad, or from public or private research centers.
L'archive ouverte pluridisciplinaire HAL, est destinée au dépôt et à la diffusion de documents scientifiques de niveau recherche, publiés ou non, émanant des établissements d'enseignement et de recherche français ou étrangers, des laboratoires publics ou privés.

\section{(1) $(1) \Theta$}

Distributed under a Creative Commons Attribution - NonCommercial - NoDerivatives 44.0 


\section{Adsorption of strontium and caesium onto an Na-illite and Na-illite/Na-smectite mixtures: implementation and application of a multi-site ion-exchange model.}

Brice Siroux ${ }^{\mathrm{a}}$, Aubéry Wissocq ${ }^{\mathrm{b}, \dagger}$, Catherine Beaucaire $^{\mathrm{b}}$, Christelle Latrille $^{\mathrm{b}}$, Cristina $^{\mathrm{a}}$ Petcut $^{\mathrm{b}}$, Jordan Calvaireb, Michel Tabaranta, Marc F. Benedettic, Pascal E. Reillera, ${ }^{\mathrm{a}}$

a Den - Service d'Études Analytiques et de Réactivité des Surfaces (SEARS), CEA, Université Paris-Saclay, F-91191 Gif-sur-Yvette, France

${ }^{b}$ Den - Service d'Études du Comportement des Radionucléides (SECR), CEA, Université Paris-Saclay, F-91191 Gif-sur-Yvette, France

c Institut de Physique du Globe de Paris, Sorbonne Paris Cité, Université Paris Diderot, UMR 7154 CNRS, F-75005 Paris, France

*corresponding author: pascal.reiller@cea.fr

+ Present address: Geo-Hyd, Parc Technologique du Clos du Moulin, 101 rue Jacques Charles, F-45160 Olivet, France.

Applied Geochemistry 99, 65-74

http://doi.org/10.1016/j.apgeochem.2018.10.024

\section{ABSTRACT}

The application of a multi-site ion-exchange (MSIE) model to the prediction of contaminant behaviour onto soils or sediments requires a coherent adsorption database. Following the same approach exposed in preceding works on smectite (Siroux et al., Appl. Geochem. 87, 167; Wissocq et al., Appl. Geochem., 93, 167), a database is here implemented to allow modelling the adsorption of radionuclides ${ }^{90} \mathrm{Sr}$ and ${ }^{137} \mathrm{Cs}$ onto Naillite, one of the major clay mineral encountered in the terrestrial environment. This database allows describing the adsorption properties of $\mathrm{Sr}^{2+}$ and $\mathrm{Cs}^{+}$competing with major cations $\mathrm{H}^{+}$- considered as the reference cation - and $\mathrm{Na}^{+}$onto an Na-illite. To obtain the adsorption site capacities and selectivity coefficients of illite sites for $\mathrm{Na}^{+}$ towards $\mathrm{H}^{+}$, a saturation curve of $\mathrm{Na}^{+}$on $\mathrm{Na}$-conditioned illite was acquired. Adsorption isotherms issued from literature have been reinterpreted using the MSIE model to obtain the adsorption properties of $\mathrm{Sr}^{2+}$ and $\mathrm{Cs}^{+}$onto purified and $\mathrm{Na}$-conditioned illite. Afterwards, the predictability and robustness of the database were verified simulating experimental adsorption of $\mathrm{Sr}^{2+}$ and $\mathrm{Cs}^{+}$onto Na-illite/Na-smectite mixtures.

Keywords: cesium; caesium; strontium; sodium; illite; adsorption; modelling; multi-site ionexchange model; additivity; clay mineral; soils 


\section{INTRODUCTION}

The development of nuclear energy requires knowledge of potential consequences on the environment. ${ }^{90} \mathrm{Sr}$ and ${ }^{137} \mathrm{Cs}$ are two of the most important daughters of uranium and plutonium fission reaction (England and Rider, 1993). Both radio-isotopes were scattered in the environment after nuclear accidents such as Chernobyl and Fukushima-Daiichi, but also from the fall-out of nuclear weapons detonations.

In soils, ${ }^{90} \mathrm{Sr}$ and ${ }^{137} \mathrm{Cs}$ are strongly adsorbed and their behaviours are mainly dominated by their interactions with clays. As clay minerals bear structural negative surface charges, the adsorption of cation, as $\mathrm{Sr}^{2+}$ and $\mathrm{Cs}^{+}$, is facilitated. The adsorption of these radionuclides onto clay minerals, such as bentonite (Galamboš et al., 2013; Montavon et al., 2006), illite (Fuller et al., 2015; Mahoney and Langmuir, 1991), kaolinite (Chen et al., 2015; Erten et al., 1988; Reinoso-Maset and Ly, 2014) or vermiculite (Dzene et al., 2015; Long et al., 2014), has been extensively studied in the literature. Illite is especially referenced as the major adsorbent for $\mathrm{Cs}^{+}$onto strong affinity low concentration sites, referred as frayed edge sites (Brouwer et al., 1983; Cremers et al., 1988; Sawhney, 1972).

Many adsorption models were developed in order to represent the adsorption behaviours of $\mathrm{Sr}^{2+}$ and $\mathrm{Cs}^{+}$onto clay minerals, sediment, or soils. In most of these models, adsorption is described as an ion-exchange (Robin et al., 2015) or a surface complexation (Nie et al., 2017) reaction. On the other hand, Bradbury and Baeyens (1999) have considered both adsorption and complexation phenomena, and have developed a model based on a mechanistic description of the cation adsorption between a clay minerals and a liquid phase - namely the two-sites protolysis non-electrostatic surface complexation and cation -exchange model or 2SPNE SC/CE.

These models, considering ion-exchange or surface complexation, are currently applied on more complex phase mixtures as soils. Many authors used a generalized composite approach, which consists in fully describing the complex material as a unique adsorbent, e.g. Motellier et al. (2003) or Jacquier et al. (2004). This approach allows a good representation of the adsorption properties of the studied material, but it often impedes the extrapolation of the obtained data onto different materials. Another approach considers the adsorption properties of a complex adsorbent as resulting from the additivity of simpler components. This approach requires a large amount of inputs data - description of adsorption reaction onto the main reactive mineral contained in the studied material - , but it allows a better extrapolation of the modelling once the database is completed. Missana et al. (2014b) have applied a model derived from the 2SPNE SC/CE and the additivity approach in order to simulate the adsorption of caesium onto two Spanish clays.

The multi-site ion-exchange (MSIE) formalism (Stammose et al., 1992), which will be used in this study, has been successfully applied in several studies. For instance, Tertre et al. 
(2009) have modelled the $\mathrm{Zn}^{2+}$ behaviour onto montmorillonite and simulated successfully its adsorption onto different soils and sediments. Reinoso-Maset and Ly (2014) have studied the adsorption of major cations such as $\mathrm{Na}^{+}, \mathrm{Ca}^{2+}, \mathrm{K}^{+}$, and $\mathrm{Mg}^{2+}$ onto pure kaolinite, and the behaviour of $\mathrm{Cs}^{+}$at trace level. Finally, the studies carrying out the adsorption of $\mathrm{Sr}^{2+}$ and $\mathrm{Cs}^{+}$onto an Na-smectite (Siroux et al., 2017), and onto Ca-illite and -smectite (Wissocq et al., 2018), served as a basis for a general adsorption database for the MSIE formalism.

Applying the additivity approach in the framework of the MSIE model enables simulating adsorption onto complex phases. The $\mathrm{Sr}^{2+}$ and $\mathrm{Cs}^{+}$adsorption onto sedimentary rock (Wissocq et al., 2018) and their mobilities in a clayey rock (Savoye et al., 2012; Savoye et al., 2015) were also successfully simulated using this approach.

The aims of this paper are: i) implementing the database for the MSIE model with the adsorption properties of $\mathrm{Na}^{+}, \mathrm{H}^{+}, \mathrm{Cs}^{+}$and $\mathrm{Sr}^{2+}$ onto Na-illite; and ii) verifying the additivity approach on Na-illite/Na-smectite mixtures using the MSIE model. First, a purified Na-conditioned illite du Puy will be described in terms of site capacity $\left(\mathrm{SC}_{\mathrm{i}}\right)$ and corrected - of adsorbed species activity coefficients - selectivity coefficients for the $\mathrm{Na}^{+} / \mathrm{H}^{+}$ exchange $\left(\mathrm{K}_{\mathrm{Na}^{+} / \mathrm{H}^{+}}^{* \mathrm{i}}\right)$ for each site. Second, adsorption isotherms of $\mathrm{Sr}^{2+}$ and $\mathrm{Cs}^{+}$onto purified and Na-conditioned illite samples will be compiled from literature and modelled in order to determine the selectivity coefficients for the $\mathrm{M}^{\mathrm{n}+} / \mathrm{nH}^{+}$exchanges $\left(\mathrm{K}_{\mathrm{M}^{\mathrm{n}}}^{* \mathrm{i}} / \mathrm{nH}^{+}\right)$. Finally, the implemented database, including the parameters from Siroux et al. (2017) for $\mathrm{Na}$-smectite, will be used to predictively simulate experimental adsorption isotherms of $\mathrm{Sr}^{2+}$ and $\mathrm{Cs}^{+}$onto illite/smectite mixtures.

\section{MATERIALS AND METHODS}

\subsection{MATERIALS}

A SWy-2 smectite purchased from the Clay Mineral Society, and an illite du Puy were used in this study. These clay minerals were purified in order to isolate the montmorillonite (SWy-2) and the illite fractions from these clay materials. The applied purification protocol consists in eliminating organic matter as much as possible with $\mathrm{H}_{2} \mathrm{O}_{2}$ at $80^{\circ} \mathrm{C}$, and

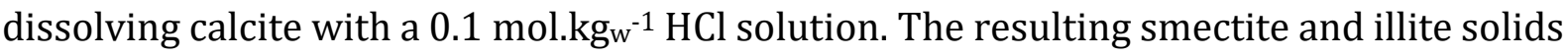
were dispersed in pure water (solid/solution ratio at 1:10) and sieved at 63 and $25 \mu \mathrm{m}$, respectively. This protocol is further detailed in Gaucher (1998), Peynet (2003), and Reinoso-Maset and Ly (2014). Both clay minerals were then Na-conditioned by five successive washings with a $1 \mathrm{~mol}$ per $\mathrm{kg}$ of water $\left(\mathrm{mol}_{\mathrm{kg}} \mathrm{kg}_{\mathrm{w}}{ }^{-1} \mathrm{NaCl}\right.$, and a final washing with a $0.1 \mathrm{~mol} \mathrm{~kg}_{\mathrm{w}}{ }^{-1} \mathrm{NaCl}$ solution. Finally, the $\mathrm{Na}$ excess was removed by rinsing with Milli-Q water (Millipore, $18.2 \mathrm{M} \Omega . \mathrm{cm}^{-2}$ ), then with ethanol. Purification and conditioning treatments for the clay minerals were confirmed by XRD analysis. The purified SWy-2 still presented traces of well-crystalized quartz and no significant trace of illite, while illite presented traces of quartz and kaolinite. 
All chemicals were at least of analytical grade. The stable Sr solutions was prepared with a $\mathrm{SrCl}_{2} \cdot 6 \mathrm{H}_{2} \mathrm{O}$ salt (99.995\% trace metals basis, Sigma Aldrich), while CsCl (99.999\% trace metals basis, Sigma Aldrich) was used for the stable Cs solutions. Radioisotopes ${ }^{85} \mathrm{Sr},{ }^{137} \mathrm{Cs}$, and ${ }^{22} \mathrm{Na}$ were provided by Cerca LEA. Ionic strength was fixed using $\mathrm{NaCl}$ (Analar Normapur, VWR).

\subsection{EXPERIMENTAL PROTOCOL}

\subsubsection{Analytical methods}

The aqueous concentrations measurements of $\mathrm{Sr}, \mathrm{Na}, \mathrm{Ca}, \mathrm{K}$, and $\mathrm{Mg}$ were determined by inductively coupled plasma atomic emission spectroscopy (ICP-AES, Activa, Horiba Jobin Yvon), diluting aliquots with $2 \%$ sub-boiling $\mathrm{HNO}_{3}$ (DuoPur, Milestone). Measurements were made using calibrations with five points at $407.771 \mathrm{~nm}$ for strontium, $589.592 \mathrm{~nm}$ for sodium, $317.933 \mathrm{~nm}$ for calcium, $766.490 \mathrm{~nm}$ for potassium, $273.553 \mathrm{~nm}$ for magnesium. The aqueous concentrations of Cs were measured by inductively coupled plasma mass spectrometry (ICP-MS, Element 2, Thermo Scientific). The $\mathrm{pH}$ values were measured with a combined microelectrode ( $\mathrm{pH}$ InLab, Mettler Toledo) by redetermination of the potential/pH plot of the electrode and by calculating the value of the solutions from their potentials (buffer solutions 4.01, 7.00, 9.18, Merck). Uncertainties from the linear regression are typically in the range of $0.05 \mathrm{pH}$-units.

\subsubsection{Characterization of clay minerals}

The cation-exchange capacity (CEC) and the exchangeable cations measurement of the purified smectite and illite were measured as in Siroux et al. (2017). The CEC measurement consists in extracting all exchangeable cations from the clay mineral with a 0.1 mol. $\mathrm{kg}_{\mathrm{w}}{ }^{-1} \mathrm{KCl}$ solution with addition of $\mathrm{KOH}$ to reach a $\mathrm{pH}$ ca. 10 . Then, adsorbed $\mathrm{K}^{+}$ was extracted with a 0.1 mol. $\mathrm{kg}_{\mathrm{w}}{ }^{-1} \mathrm{CsCl}$ solution then measured by ICP-AES (Table 1). The sum of the exchangeable cations is close to the measured CEC. As expected, sodium is the major exchangeable cation in purified clay minerals but there are still traces of $\mathrm{K}^{+}$and $\mathrm{Mg}^{2+}$. 
Table 1. Exchangeable cations concentrations and CEC measurement of purified Naclay minerals.

\begin{tabular}{|c|c|c|c|c|c|c|}
\hline \multicolumn{7}{|c|}{ Exchangeable cations } \\
\hline Sample & $\begin{array}{c}\mathrm{Na} \\
\text { (meq.100g-1) }\end{array}$ & $\begin{array}{c}\text { Ca } \\
(\text { meq.100g-1) }\end{array}$ & $\begin{array}{c}\mathrm{Mg} \\
\left(\mathrm{meq}^{\left.-100 \mathrm{~g}^{-1}\right)}\right.\end{array}$ & $\begin{array}{c}\mathrm{K} \\
(\text { meq.100g-1) }\end{array}$ & $\begin{array}{c}\text { Sum of } \\
\text { exchangeable } \\
\text { cations } \\
\text { (meq.100g-1) }\end{array}$ & $\begin{array}{c}\text { CEC } \\
\left(\text { meq.100g-1) }^{-1}\right)\end{array}$ \\
\hline $\begin{array}{c}\text { Swy-2 } \\
\text { smectite }\end{array}$ & 79 & $<$ l.o.d. & 0.4 & 2.5 & 81.9 & 83.3 \\
\hline Illite du Puy & 19.6 & < l.o.d. & < l.o.d. & 1.1 & 20.7 & 20.9 \\
\hline
\end{tabular}

l.o.d: limit of detection

\subsubsection{Na-saturation curve and adsorption isotherm onto pure clay mineral mixtures}

Experiments were done by batch method at room temperature $\left(22 \pm 5^{\circ} \mathrm{C}\right)$ in $10 \mathrm{~mL}$ polycarbonate Nalgene centrifuge tubes (3138-0010, Thermo Scientific). All solutions and suspensions were made by weighing. All equilibration and agitation of the suspensions were done using an orbital shaker.

Saturation curve of $\mathrm{Na}^{+}$onto pure Na-illite was made with a $19 \mathrm{~g} . \mathrm{L}^{-1} \mathrm{~S} / \mathrm{L}$ ratio. A $0.1 \mathrm{~g}$ of illite aliquot was dispersed in $5 \mathrm{~mL}$ of $0.02 \mathrm{~mol} \mathrm{~kg}_{\mathrm{w}}{ }^{-1} \mathrm{NaCl}$ and equilibrated during $24 \mathrm{~h}$. Solutions of $1,0.1$, or 0.01 mol. $\mathrm{kg}_{\mathrm{w}}{ }^{-1}$ of either $\mathrm{HCl}$ or $\mathrm{NaOH}$ were used in order to adjust the $\mathrm{pH}$ of the suspensions to values ranged between 3 and 11. Suspensions were then equilibrated during ca. $24 \mathrm{~h}$, and subsequently spiked with ${ }^{22} \mathrm{Na}-300 \mu \mathrm{L}$ of $\mathrm{NaCl}$ in $\mathrm{HCl}$ $0.1 \mathrm{~N}$ added containing $13 \mathrm{kBq} / \mathrm{mL}^{22} \mathrm{Na}$ - and equilibrated during 7 days. Suspensions were ultra-centrifuged at 33,000 $\mathrm{g}$ during $30 \mathrm{~min}$ (Beckman Optima LE-80K, Beckman Ultracentrifuge); $1 \mathrm{~mL}$ aliquots of the supernatants were collected, and activity was counted by gamma counting (1480 Wizard 3, Perkin Elmer). Total Na content (stable and radioisotope) was analysed by ionic chromatography (standard Chem-Lab).

The partition coefficients $\mathrm{R}_{\mathrm{D}}\left(\mathrm{L} . \mathrm{kg}^{-1}\right)$ were calculated using,

$$
\mathrm{R}_{\mathrm{D}}=\left(\frac{\mathrm{C}_{0}}{\mathrm{C}_{\mathrm{eq}}}-1\right) \cdot \frac{V}{m}
$$

where $\mathrm{C}_{0}$ and $\mathrm{C}_{\text {eq }}$ are respectively the initial and equilibrium activities of $\mathrm{Na}, \mathrm{Sr}$, or $\mathrm{Cs}, V$ is the total volume of solution (L), and $m$ is the total dry mass of solid (kg).

The initial activities were determined using a blank procedure, i.e. using the same protocol without clay minerals in batches. The adsorbed concentrations were then calculated from the initial concentrations and the partition coefficient.

Pure clay mixtures experiments were prepared by weighing, and dry mechanic stirring the dried pure minerals. In these experiments, a 3.8 g. $\mathrm{L}^{-1}$ solid/solution ratio was used. 
Illite/smectite mixtures were first equilibrated with a 0.1 mol. $\mathrm{kg}_{\mathrm{w}}{ }^{-1} \mathrm{NaCl}$ electrolyte for 24 hours. The $\mathrm{pH}$ was adjusted ca. 7 with $1,0.1$, or $0.01 \mathrm{~mol}^{\mathrm{kg}} \mathrm{kw}^{-1}$ solutions of either $\mathrm{HCl}$ or $\mathrm{NaOH}$, and suspensions were left under agitation for ca. $24 \mathrm{~h}$. The concentration of stable caesium - from $10^{-9}$ to $10^{-2}$ mol. $\mathrm{kg}_{\mathrm{w}}{ }^{-1} \mathrm{in} \mathrm{CsCl}$ - or strontium - from $10^{-6}$ to $10^{-2}$ mol. $\mathrm{kg}_{\mathrm{w}}{ }^{-1}$ in $\mathrm{SrCl}_{2}$ - was added in the centrifuge tubes. Suspensions were also spiked with ${ }^{85} \mathrm{Sr}$ or ${ }^{137} \mathrm{Cs}$ (ca. 3,000 Bq), then left under agitation during two and five days for Sr and $\mathrm{Cs}$, respectively. Finally, the suspensions were ultra-centrifuged at 90,000 g during 30 min. (Beckman Optima LE-80R, Beckman Ultracentrifuge); $1 \mathrm{~mL}$ aliquots of the supernatants were collected, and activity was counted by gamma counting. The initial concentrations of Sr were determined in ICP-AES, and the Cs concentrations in ICP-MS.

\subsubsection{Verification of the additivity approach}

Purified and Na-conditioned SWy-2 smectite and illite du Puy were used for these experiments. Two mixtures were prepared by mechanical mixing powder of purified clay minerals. The exact percentages of each clay mineral mixture are detailed in Table 2. For M1 and M2 mixtures, adsorption isotherms of $\mathrm{Cs}^{+}$and $\mathrm{Sr}^{2+}$ vs. concentration were acquired at $\mathrm{pH} 7$ and $\mathrm{I}=0.1 \mathrm{~mol} \cdot \mathrm{kg}_{\mathrm{w}}{ }^{-1} \mathrm{NaCl}$.

Table 2. Percentage of Na-illite and Na-smectite in M1 and M2 mixtures

\begin{tabular}{lcc}
\hline Sample & \% illite & \% smectite \\
\hline M1 & 30.2 & 69.8 \\
M2 & 70.1 & 29.9 \\
\hline
\end{tabular}

\subsection{ModeLLING}

Isotherms were modelled using the MSIE model, which is fully detailed elsewhere (Jacquier et al., 2004; Motellier et al., 2003; Reinoso-Maset and Ly, 2014; Savoye et al., 2012; Savoye et al., 2015; Siroux et al., 2017; Stammose et al., 1992; Tertre et al., 2009; Wissocq et al., 2018). Briefly, in this model clay minerals are defined as exchangers with different charged adsorption sites $\left(\mathrm{X}_{\mathrm{i}}^{-}\right)$, which are expressed in terms of site capacities $\left(\mathrm{SC}_{\mathrm{i}}\right)$ and corrected - of adsorbed species activity coefficients - selectivity coefficients for a $\mathrm{Na}^{+} / \mathrm{H}^{+}$exchange $\left(\mathrm{K}_{\mathrm{Na}^{+} / \mathrm{H}^{+}}^{*}\right)$. Sites capacities are obtained from the Na-saturation isotherm describing the cation saturation of the homo-ionic exchanger vs. $\mathrm{pH}$. The equilibrium between $\mathrm{Na}^{+}$and $\mathrm{H}^{+}$on negatively charge type of site $\mathrm{X}_{\mathrm{i}}^{-}$is expressed by the following equilibrium reaction.

$$
\overline{\mathrm{X}_{1}^{-}-\mathrm{Na}^{+}}+\mathrm{H}^{+} \rightleftarrows \overline{\mathrm{X}_{1}^{-}-\mathrm{H}^{+}}+\mathrm{Na}^{+}
$$

The equilibrium constant of this equation can be written as, 


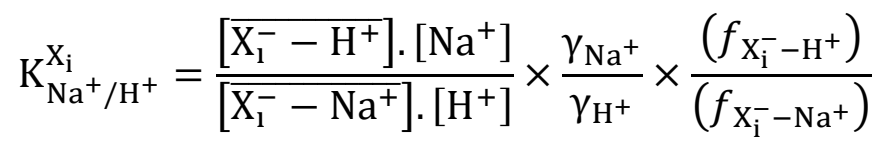

where [ ] is the solution (mol. $\mathrm{kg}_{\mathrm{w}}{ }^{-1}$ ) concentration, $\left.{ }^{-}\right]$is the adsorbed concentration (mol.kg-1 of solid) of species, $\gamma$ are the activity coefficients of aqueous species - calculated here using Davies (1962) equation - , and $f$ are activity coefficients of adsorbed species.

Since the activity coefficients of adsorbed species $f$ are not known, it is assumed that the ratio between these coefficients is constant. Thus, the apparent constants - called corrected selectivity coefficients $\mathrm{K}_{\mathrm{Na}^{+} / \mathrm{H}^{+}}$- are expressed as follows.

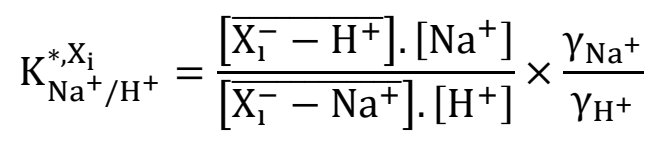

It is worthy to notice that the exchanger is supposed not to undergo any phase modification when a physicochemical parameter of the solution is changed, e.g. pH, ionic strength, temperature...

Sites $i$ are also described by their site capacities $\mathrm{SC}_{\mathrm{i}}$ in mol.kg-1 of solid, which equals to the sum of the adsorbed species concentrations.

$$
\mathrm{SC}_{\mathrm{i}}=\left[\overline{\mathrm{X}_{1}^{-}-\mathrm{H}^{+}}\right]+\left[\overline{\mathrm{X}_{1}^{-}-\mathrm{Na}^{+}}\right]
$$

In the present study, sites capacities are obtained from the Na-saturation curve describing the cation saturation of the homo-ionic exchanger, express in term of adsorbed species concentration (mol/kg of solid) vs. pH. Each site exchange capacity is expressed by a plateau corresponding to an $\mathrm{Na}^{+} / \mathrm{H}^{+}$exchange reaction.

The corrected selectivity coefficients associated to the trace element $\left(\mathrm{Sr}^{2+}\right.$ and $\left.\mathrm{Cs}^{+}\right)$ exchanged with $\mathrm{Na}^{+}$are determined fitting the adsorption isotherms of these trace elements onto homo-ionic Na-conditioned exchanger vs. the solution $\mathrm{pH}$ or the equilibrium concentration of the trace element in solution. The corrected selectivity coefficient for the $\mathrm{M}^{\mathrm{m}+} / \mathrm{Na}^{+}$exchange is written as follows.

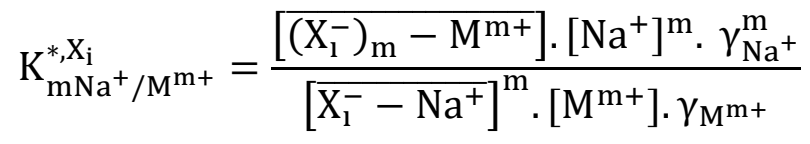

Calculation of $\left[\overline{\left(\mathrm{X}_{1}^{-}\right)_{\mathrm{m}}-\mathrm{M}^{\mathrm{m}+}}\right]$ permits calculating experimental partition coefficient $\mathrm{R}_{\mathrm{D}}$ using the following expression:

$$
\mathrm{R}_{\mathrm{D}}=\frac{[\overline{\mathrm{M}}]}{[\mathrm{M}]}=\frac{\sum_{\mathrm{i}}\left[\overline{\left.\left.\mathrm{X}_{1}^{-}\right)_{\mathrm{m}}-\mathrm{M}^{\mathrm{m}+}\right]}\right.}{[\mathrm{M}]}
$$


In case of illite/smectite mixtures, the total adsorption of $\mathrm{M}^{\mathrm{m}+}$ arises from each mass fraction contribution as follows.

$$
\mathrm{R}_{\mathrm{D}}=\frac{\sum_{\mathrm{i}}\left[\overline{\left(\mathrm{X}_{1}^{-}\right)_{\mathrm{m}}-\mathrm{M}^{\mathrm{m}+}}\right]_{\mathrm{illite}}+\sum_{\mathrm{j}}\left[\overline{\left(\mathrm{Y}_{\mathrm{J}}^{-}\right)_{\mathrm{m}}-\mathrm{M}^{\mathrm{m}+}}\right]_{\text {smectite }}}{[\mathrm{M}]}
$$

Uncertainties on $\mathrm{R}_{\mathrm{D}}$ are determined by propagation of errors. However, due to its low value, $\mathrm{R}_{\mathrm{D}}$ error bar expressed by the $\mathrm{R}_{\mathrm{D}}$ standard deviation calculated on three replicates was preferred - estimated to $0.15 \log$ unit to compare the experimental data.

\section{RESULTS AND DISCUSSION}

\subsection{PRELIMINARY REMARKS}

As stated in Siroux et al. (2017) for Na-smectite, illite was supposed to be fully Na-homoionic. Despite their possible interactions in the adsorption processes, other exchangeable cations - e.g. $\mathrm{K}^{+}$present in the exchanger - were neglected to interpret the adsorption results. Their trace level concentrations were assumed sufficiently low not to interfere with $\mathrm{Cs}^{+}$and $\mathrm{Sr}^{2+}$. Furthermore, it is known that $\mathrm{pH}<4$ or $\mathrm{pH}>10$ the dissolution of clay minerals can be significant (Amram and Ganor, 2005; Bradbury and Baeyens, 1997), and can lead to a release of aluminium, silicon, iron, and other structural cations as $\mathrm{K}^{+}$and $\mathrm{Mg}^{2+}$. The release of these ions - mainly $\mathrm{Al}(\mathrm{OH})_{\mathrm{n}}^{(3-n)+}$ or $\mathrm{Fe}(\mathrm{OH})_{\mathrm{n}}^{(3-\mathrm{n})+}$ - could compete with the adsorption of $\mathrm{Sr}^{2+}$ and $\mathrm{Cs}^{+}$onto illite. The account of these phenomena is very difficult to manage, see e.g. Bradbury and Baeyens (2005). One must not forget that these phenomena are intrinsically included into the corrected selectivity coefficients. However, $\mathrm{Al}$ and Fe in compensating charge, as enhanced surface charges due to dissolution, may generate erratic $\mathrm{K}_{\mathrm{D}}$ values at extreme $\mathrm{pH}$. In our experiments, $\mathrm{K}_{\mathrm{D}}$ value are coherent with a global trend of adsorption. Moreover, for this study, dissolutions tests performed on illite revealed a silicon lost estimated below $0.5 \%$ at $\mathrm{pH} 3$ under our experimental conditions, i.e. $m / V=19$ g. $\mathrm{L}^{-1}, 15$ days of contact time. Therefore, the dissolution effect on adsorption properties have been neglected.

\subsection{DATABASE IMPLEMENTING}

The first part of this study consists in implementing the database originally built from the works of Siroux et al. (2017) and Wissocq et al. (2018) with the adsorption behaviour of $\mathrm{Sr}^{2+}$ and $\mathrm{Cs}^{+}$onto an Na-illite. This database was built from experimental data available in the literature that follows several criteria: i) the illite must be purified; ii) the illite must be Na-conditioned; and iii) adsorption isotherms must be acquired with $\mathrm{Na}^{+}$electrolyte $\left(\mathrm{NaCl}\right.$ or $\left.\mathrm{NaClO}_{4}\right)$. In case of saturation isotherm, $\mathrm{Na}^{+}$adsorption isotherms have to attain the CEC of illite as close as possible. As it will be discussed in the following, in order to respect this latter criterion, a new saturation curve was acquired. 
In some cases the original experimental data were directly extracted from Tables of the paper or manuscript, or their retrieval was made using WinDig (1996) data digitizer software. Once the data were retrieved, the MSIE modelling was applied in order to determine the selectivity coefficients by fitting the model to the data with the MS Excel Solver. Fitting uncertainties were finally obtained using the SolverAid macro from De Levie (2004).

\subsubsection{Saturation of illite with $\mathrm{Na}^{+}$}

As already detailed elsewhere (Siroux et al., 2017; Wissocq et al., 2018), the capacity of major adsorption sites is generally deduced from saturation curves expressed in terms of the concentration of adsorbed species ( $\mathrm{mol} / \mathrm{kg}$ of solid) over a wide range of $\mathrm{pH}$ values (2 to 11). These curves are acquired for each major cation of interest, onto homo-ionic clay minerals, and under chemical conditions leading to the saturation of site capacities. Each site exchange capacity is expressed by a plateau, corresponding to an exchange reaction at equilibrium between cation and proton, which determines the site capacity $\mathrm{CE}_{\mathrm{i}}$. So, illite must be characterized in terms of $\mathrm{SC}_{\mathrm{i}}$ and $\mathrm{K}_{\mathrm{Na}^{+} / \mathrm{H}^{+}}^{*}$ studying the saturation of an Na-illite by $\mathrm{Na}^{+}$vs. pH. Ly et al. (1991) and Gorgeon (1994) have previously studied the $\mathrm{Na}^{+}$ saturation onto illite du Puy at $[\mathrm{Na}]=0.02$ mol. $\mathrm{kg}_{\mathrm{w}}{ }^{-1}$ : the results are recalled in Fig. 1. It appears that the saturation curve of these authors increases with $\mathrm{pH}$, and then levels-off to 16.7 meq. $100 \mathrm{~g}^{-1}$ at $\mathrm{pH} 11.5$. It seems that $\mathrm{Na}^{+}$did not fully saturate the illite - CEC measured at 0.248 eq. $\mathrm{kg}^{-1}$ on $\mathrm{a}<80 \mu \mathrm{m}$ fraction by Gorgeon (1994).

As our illite du Puy sample has been purified differently from Gorgeon (1994), new experimental points obtained in this study are also shown in Fig. 1. At acidic $\mathrm{pH}$, the curve follows those from Gorgeon (1994) but instead of levelling off, the experimental points continue increasing until $[\mathrm{Na}]_{\text {ads }}=22$ meq.100 $\mathrm{g}^{-1}$. Contrary to Gorgeon (1994), sodium seems to saturate the Na-illite and achieves a concentration close to the CEC. 


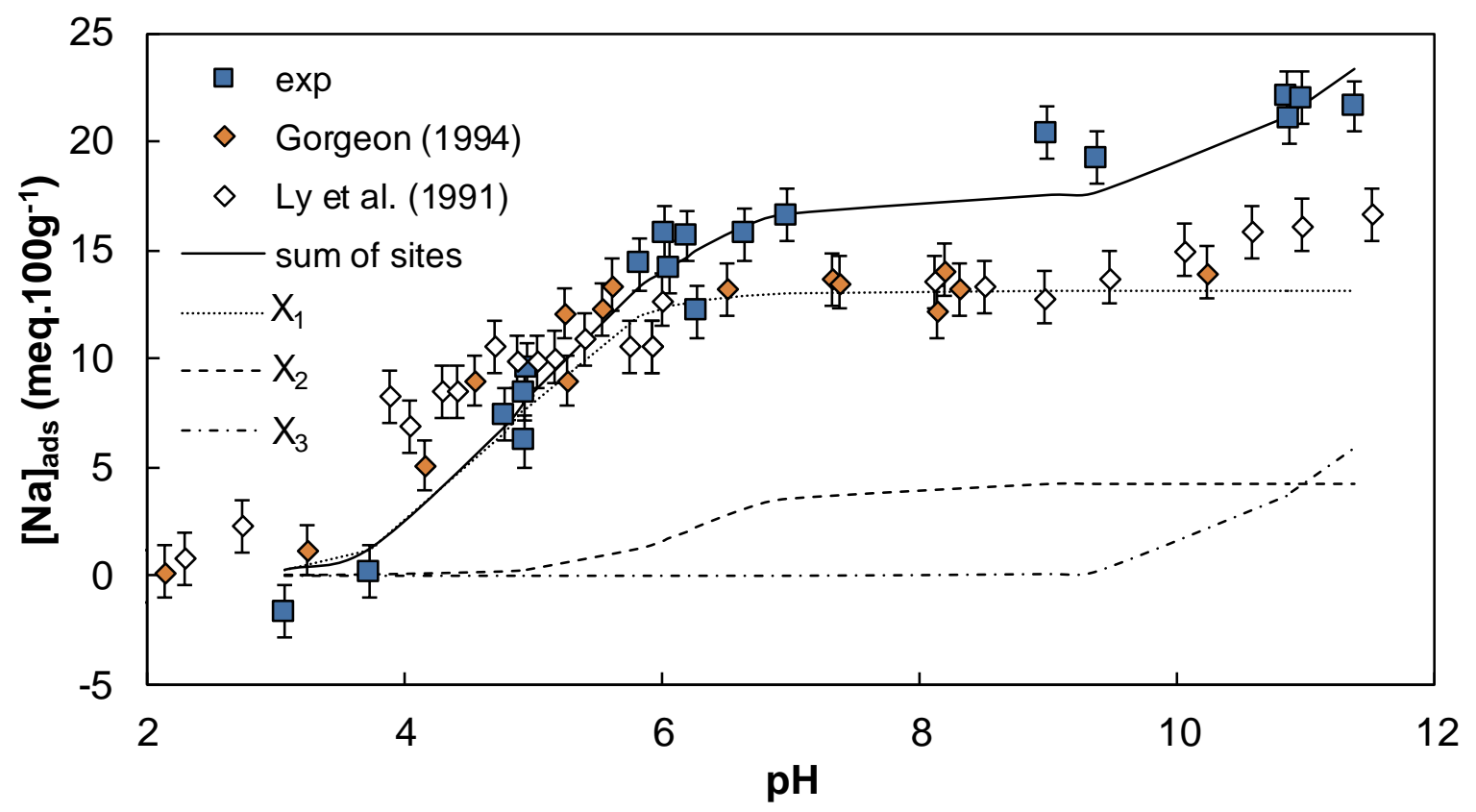

Fig. 1. Saturation curve of Na-illite (squares) vs. $\mathrm{pH}$ at I $\left.=0.02 \mathrm{~mol}^{-\mathrm{kg}_{\mathrm{w}}} \mathrm{-}^{-1} \mathrm{NaCl}\right)$ and $\mathrm{S} / \mathrm{L}$ ratio $=19 \mathrm{~g} . \mathrm{L}^{-1}$, and representation of the modelling and the influence of the different fixation sites, compared to the results from Gorgeon (1994) (filled diamonds) and Ly et al. (1991) - empty diamonds digitized from Gorgeon (1994).

The site capacities determined by Gorgeon (1994) and Wissocq et al. (2018) — who have implemented the database for the adsorption of $\mathrm{Cs}^{+}$and $\mathrm{Sr}^{2+}$ onto a Ca-illite within the same MSIE formalism - coincide perfectly with the present new Na-saturation curve. So, for the sake of consistency the SCi determined in the literature were used. This new saturation curve permits to adjust the selectivity coefficient more precisely, as the total CEC is now saturated. The $\mathrm{SC}_{\mathrm{i}}$ and new $\log _{10} \mathrm{~K}_{\mathrm{Na}^{+} / \mathrm{H}^{+}}^{*}$ are recalled in Table 3. The modelling satisfactorily follows the evolution of the experimental results. 
Table 3. Summary of the site capacities and selectivity coefficients obtained and used in this study

\begin{tabular}{|c|c|c|c|c|c|}
\hline Mineral & Site & $\begin{array}{c}\text { Site capacity } \\
\left(\mathrm{mmol.100g}^{-1}\right)\end{array}$ & $\begin{array}{l}\text { Selectivity } \\
\text { coefficient }\end{array}$ & $\begin{array}{c}\text { Selectivity } \\
\text { coefficient } \\
\text { value }\end{array}$ & References \\
\hline \multirow[t]{12}{*}{ Illite } & \multirow[t]{3}{*}{$\mathrm{X}_{0}$} & \multirow[t]{3}{*}{$0.1^{\mathrm{a}}$} & $\log _{10} \mathrm{~K}_{\mathrm{Na}^{+} / \mathrm{H}^{+}}^{*}$ & $2.02 \pm 1.15$ & \multirow[t]{12}{*}{ This study } \\
\hline & & & $\log _{10} \mathrm{~K}_{\mathrm{Sr}^{2+} / 2 \mathrm{H}^{+}}$ & - & \\
\hline & & & $\log _{10} \mathrm{~K}_{\mathrm{Cs}^{+} / \mathrm{H}^{+}}^{*, \mathrm{X}_{0}}$ & $-4.57 \pm 0.01$ & \\
\hline & \multirow[t]{3}{*}{$\mathrm{X}_{1}$} & \multirow{3}{*}{$13.1 \pm 0.8^{\mathrm{a}}$} & $\log _{10} \mathrm{~K}_{\mathrm{Na}^{+} / \mathrm{H}^{+}}^{*, \mathrm{X}_{1}}$ & $2.77 \pm 0.10$ & \\
\hline & & & $\log _{10} \mathrm{~K}_{\mathrm{Sr}^{2+} / 2 \mathrm{H}^{+}}$ & $3.75 \pm 0.12$ & \\
\hline & & & $\log _{10} \mathrm{~K}_{\mathrm{Cs}^{*} / \mathrm{H}^{+}}^{*}$ & $0.17 \pm 0.12$ & \\
\hline & \multirow[t]{3}{*}{$\mathrm{X}_{2}$} & \multirow[t]{3}{*}{$4.3 \pm 0.8^{\mathrm{a}}$} & $\log _{10} \mathrm{~K}_{\mathrm{Na}^{+} / \mathrm{H}^{+}}^{*} \mathrm{X}_{2}$ & $4.19 \pm 0.27$ & \\
\hline & & & $\log _{10} \mathrm{~K}_{\mathrm{Sr}^{2+} / 2 \mathrm{H}^{+}}^{*, \mathrm{X}_{2}}$ & $6.00 \pm 0.42$ & \\
\hline & & & $\log _{10} \mathrm{~K}_{\mathrm{Cs}^{*} / \mathrm{H}^{+}}^{*}$ & $<8.03^{b}$ & \\
\hline & \multirow[t]{3}{*}{$\mathrm{X}_{3}$} & \multirow[t]{3}{*}{$7.4 \pm 1.5^{\mathrm{a}}$} & $\log _{10} \mathrm{~K}_{\mathrm{Na}^{+} / \mathrm{H}^{+}}^{*, \mathrm{X}_{3}}$ & $8.95 \pm 0.18$ & \\
\hline & & & $\log _{10} \mathrm{~K}_{\mathrm{Sr}^{2+} / 2 \mathrm{H}^{+}}^{*}$ & $14.44 \pm 0.33$ & \\
\hline & & & $\log _{10} \mathrm{~K}_{\mathrm{Cs}^{+} / \mathrm{H}^{+}}^{*, \mathrm{X}_{3}}$ & $4.38 \pm 0.20$ & \\
\hline \multirow[t]{9}{*}{ Smectite } & \multirow[t]{3}{*}{$\mathrm{Y}_{1}$} & \multirow[t]{3}{*}{$38.7 \pm 3.8$} & $\log _{10} \mathrm{~K}_{\mathrm{Na}^{+} / \mathrm{H}^{+}}^{*, \mathrm{Y}_{1}}$ & $0.24 \pm 0.04$ & \multirow[t]{9}{*}{ Siroux et al. (2017) } \\
\hline & & & $\log _{10} \mathrm{~K}_{\mathrm{Sr}^{2+} / 2 \mathrm{H}^{+}}^{*}$ & $0.20 \pm 0.07$ & \\
\hline & & & $\log _{10} \mathrm{~K}_{\mathrm{Cs}^{+} / \mathrm{H}^{+}}^{*, \mathrm{Y}_{1}}$ & $-1.31 \pm 0.04$ & \\
\hline & \multirow[t]{3}{*}{$\mathrm{Y}_{2}$} & \multirow[t]{3}{*}{$36.1 \pm 6.8$} & $\log _{10} \mathrm{~K}_{\mathrm{Na}^{+} / \mathrm{H}^{+}}^{*, \mathrm{Y}^{\prime}}$ & $2.62 \pm 0.09$ & \\
\hline & & & $\log _{10} \mathrm{~K}_{\mathrm{Sr}^{2+} / 2 \mathrm{H}^{+}}^{*}$ & $4.24 \pm 0.17$ & \\
\hline & & & $\log _{10} \mathrm{~K}_{\mathrm{Cs}^{+} / \mathrm{H}^{+}}^{* \mathrm{Y}_{2}}$ & $1.64 \pm 0.17$ & \\
\hline & \multirow[t]{3}{*}{$\mathrm{Y}_{3}$} & \multirow[t]{3}{*}{$13.9 \pm 9.2$} & $\log _{10} \mathrm{~K}_{\mathrm{Na}^{+} / \mathrm{H}^{+}}^{*, Y_{3}}$ & $8.45 \pm 0.18$ & \\
\hline & & & $\log _{10} \mathrm{~K}_{\mathrm{Sr}^{2+} / 2 \mathrm{H}^{+}}^{*}$ & $13.99 \pm 0.22$ & \\
\hline & & & $\log _{10} \mathrm{~K}_{\mathrm{Cs}^{+} / \mathrm{H}^{+}}^{*} \mathrm{Y}_{3}$ & $7.77 \pm 0.37$ & \\
\hline
\end{tabular}

\subsubsection{Adsorption isotherms of trace elements}

The only studies that reach the selection criteria - cf. $\S 3.2-$ are the adsorption isotherms of $\mathrm{Sr}^{2+}$ and $\mathrm{Cs}^{+}$onto Na-illite from Poinssot et al. (1999a, 1999b). These authors provided $\mathrm{pH}$-isotherms at two different ionic strengths and a concentration isotherm for each cation. Reinterpretation of these data in the framework of the MSIE is provided.

\subsubsection{Caesium adsorption}

For the sake of consistency, the selectivity coefficients for the $\mathrm{Cs}^{+} / \mathrm{H}^{+}$exchange were determined by a simultaneous adjustment of the $\mathrm{pH}$ - and concentration-isotherms from 
Poinssot et al. (1999a, 1999b). As already explained in Siroux et al. (2017), Gorgeon (1994) and Poinssot et al. (1999a, 1999b) also reported trace $\mathrm{Cs}^{+}$adsorption onto a pure

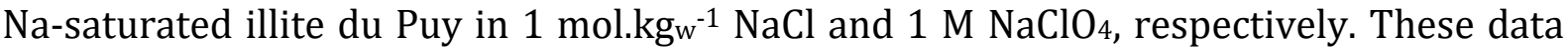
will not be included in our discussion because the ionic strength is well outside the validity domain of the Davies (1962) equation that is used within the adsorption database - see Siroux et al. (2017) and Wissocq et al. (2018), and references therein.

The adsorption isotherms of $\mathrm{Cs}^{+}$vs. $\mathrm{pH}$ at ionic strength 0.1 and $0.01 \mathrm{M} \mathrm{NaClO}_{4}-$ i.e. 0.101 and 0.010 mol. $\mathrm{kg}_{\mathrm{w}}{ }^{-1}$ (Novotny and Sohnel, 1988) —, their modelling, and the contribution of the different exchange sites are shown in Fig. 2. The adsorption of $\mathrm{Cs}^{+}$seems to depend weakly upon $\mathrm{pH}$ values. From very acidic $\mathrm{pH}, \mathrm{R}_{\mathrm{D}}$ values increase steadily then reach a plateau at $\mathrm{pH}$ ca. 4. The modelling represents well the experimental data for the $\mathrm{pH}$-adsorption isotherms at $\mathrm{I}=0.1 \mathrm{M}$ (Fig. 2a), and only three out of the four sites are necessary: the $\mathrm{X}_{2}$ site contributes weakly to the adsorption of $\mathrm{Cs}^{+}-$the contribution to the total $\mathrm{R}_{\mathrm{D}}$ value is lower than $10^{-4} \mathrm{~L}^{\mathrm{kg}}{ }^{-1}$. In view of the modelling, it is also possible to state that the $\mathrm{X}_{0}$ site drives the adsorption of $\mathrm{Cs}^{+}$.

Fig. 3 shows the adsorption isotherm of $\mathrm{Cs}^{+}$vs. equilibrium concentration. This isotherm permits distinguishing specific adsorption behaviours. At the lowest concentration, the adsorption of $\mathrm{Cs}^{+}$reaches a plateau, and then decreases at the $\mathrm{X}_{0}$ site saturation. A change in slope occurs at $\log _{10}[\mathrm{Cs}]_{\text {eq }}$ ca. -7 , which highlights the contribution of the $\mathrm{X}_{1}$ site at higher total Cs concentration. As in Fig. 2, only two of the exchange sites contributions appear in Fig. 3 because they drive the adsorption at this $\mathrm{pH}$, i.e. $\mathrm{pH}$ 7. In term of reactivity, the $\mathrm{X}_{0}$ site can be compared to the low concentration high affinity frayed edge site (FES), known to be present in illite (Brouwer et al., 1983; Missana et al., 2014b; Poinssot et al., 1999a, b; Sawhney, 1972), and also in micaceous minerals (Zaunbrecher et al., 2015) or vermiculite (Dzene et al., 2015).

At I = 0.01 M (Fig. 2b), the isotherm is overestimated by the modelling. Poinssot et al. (1999a) obtained a similar and unexplained modelling result. Studying the stability of the illite, Poinssot et al. (1999a) have observed a leaching of $\mathrm{K}^{+}$in solution, which could compete with $\mathrm{Cs}^{+}$and lower its adsorption. Bradbury and Baeyens (2005) also supposed that this overestimation could come from the dissolution - leaching of measured $\mathrm{Al}, \mathrm{Mg}$, and $\mathrm{Ca}$ - of illite and proposed to take into account the behaviour of these $\mathrm{pH}$-leached metals. Applying this proposition requires a measurement of the cationic content in equilibrium solutions and a thermodynamic characterization of the dissolution of clay minerals — see e.g. Gailhanou et al. $(2012 ; 2017)$ — , which was not available in Poinssot et al. (1999a). 


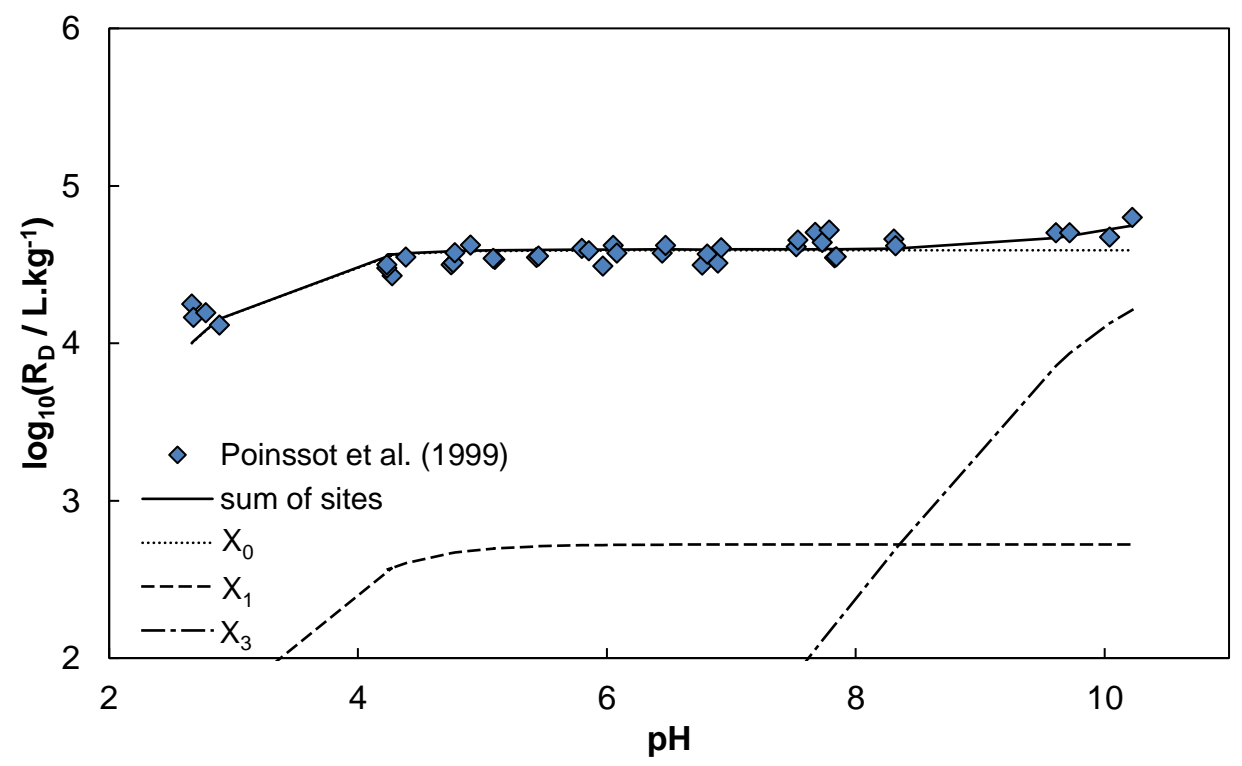

b

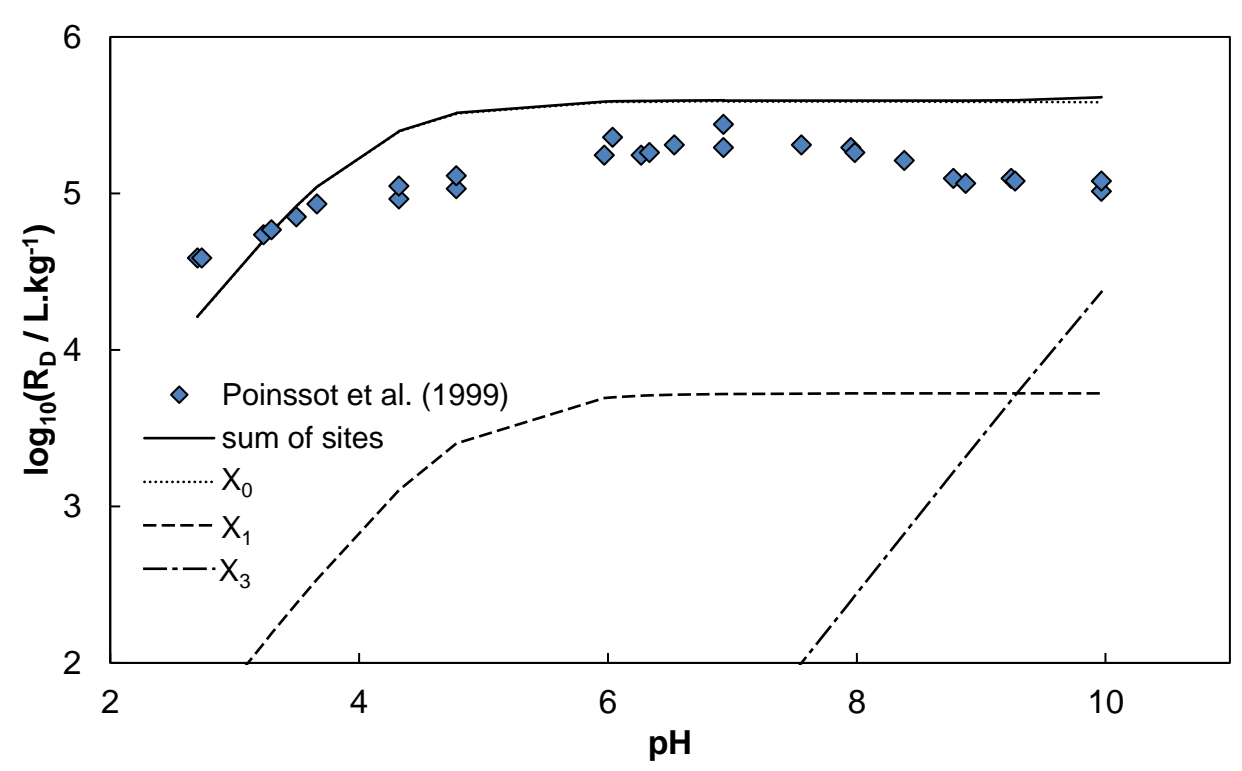

Fig. 2. Adsorption isotherm of Cs vs. pH onto Na-illite at ionic strength 0.1 (a) and 0.01 (b) $\mathrm{M}\left(\mathrm{NaClO}_{4}\right)$ and $[\mathrm{Cs}]_{\text {total }}<1^{-8} \mathrm{M}$, and modelling with the MSIE formalism. Data digitized from Poinssot et al. (1999a, 1999b). The $X_{2}$ weak contribution to $\log _{10} R_{D}$ does not appear in this representation. 


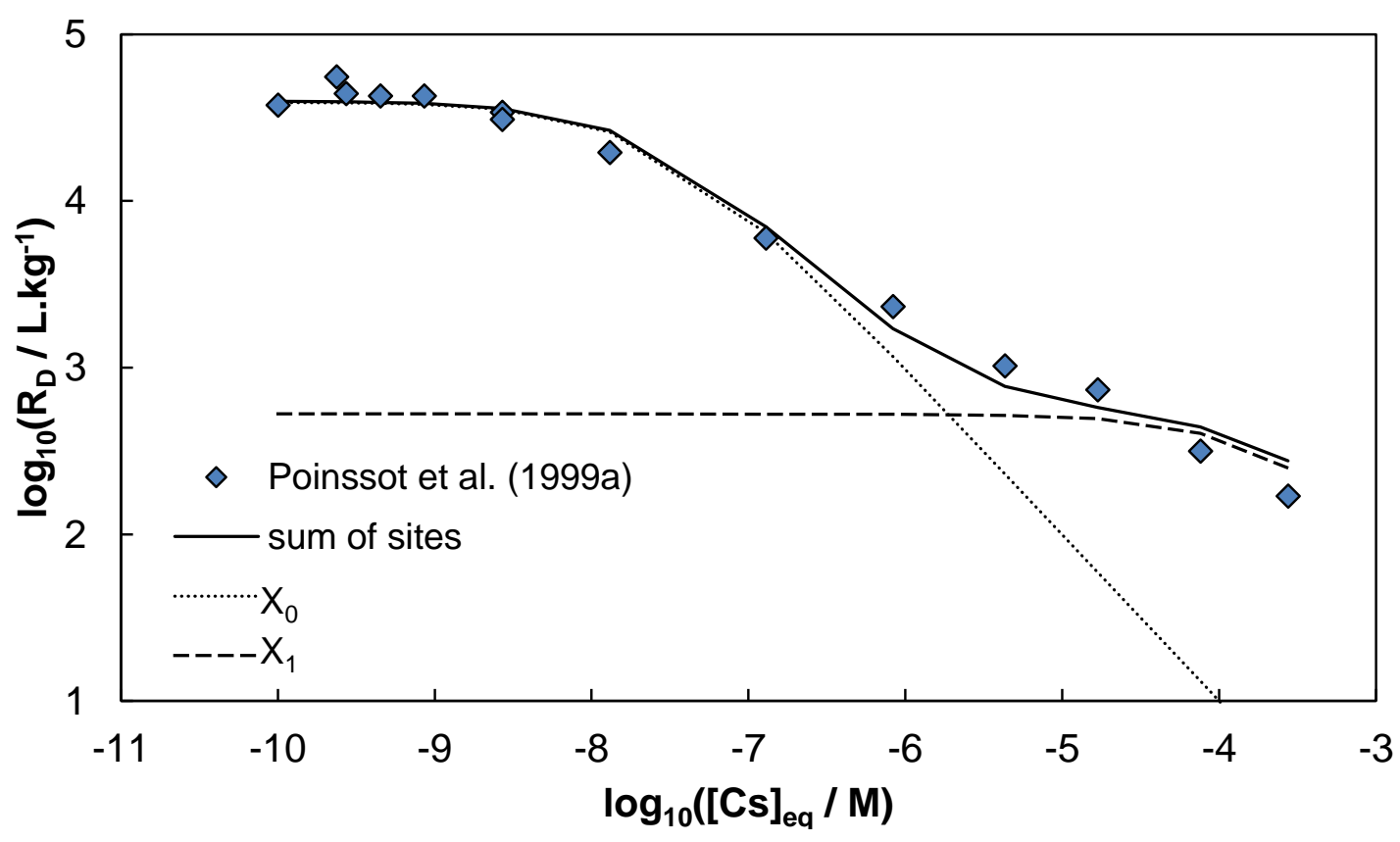

Fig. 3. Adsorption isotherm of Cs vs. equilibrium concentration onto an Na-illite at $\mathrm{I}=0.1 \mathrm{M}\left(\mathrm{NaClO}_{4}\right), \mathrm{pH}$ 7, and modelling with the MSIE formalism. Data digitized from Poinssot et al. (1999a). The $X_{2}$ and $X_{3}$ weak contributions to $\log _{10} R_{D}$ at $p H 7$ do not appear in this representation.

The fitted values for $\log _{10} \mathrm{~K}_{\mathrm{Cs}^{+} / \mathrm{H}^{+}}^{*, \mathrm{X}_{\mathrm{i}}}$ are summarized in Table 3. These selectivity coefficients - especially associated to the $\mathrm{X}_{0}$ site, which is showing a similar reactivity to FES - can be compared with literature data. Missana et al. (2014a) proposed a $\log 10 \mathrm{~K}_{\mathrm{Na}^{+} / \mathrm{Cs}^{+}}^{* \mathrm{FES}}=6.90$ comparable with the one from Poinssot et al. (1999a, 1999b), i.e. 6.95. In our case, we obtain a similar value with data from Table 3.

$$
\log _{10} \mathrm{~K}_{\mathrm{Na}^{+} / \mathrm{Cs}^{+}}^{*, \mathrm{X}_{0}}=\log _{10} \mathrm{~K}_{\mathrm{Na}^{+} / \mathrm{H}^{+}}^{*, \mathrm{X}_{0}}-\log _{10} \mathrm{~K}_{\mathrm{Cs}^{+} / \mathrm{H}^{+}}^{*, \mathrm{X}_{0}}=6.59 \pm 1.15
$$

\subsubsection{Strontium adsorption}

The strontium adsorption isotherms onto the purified Na-illite du Puy were extracted from Poinssot et al. (1999b) and Altmann et al. (2015). The selectivity coefficients of the $\mathrm{Sr}^{2+} / 2 \mathrm{H}^{+}$exchange were also determined by simultaneous adjustment of all the adsorption isotherms vs. $\mathrm{pH}$ in Fig. 4, and vs. equilibrium concentration in Fig. 5. Missana et al. (2008) also obtained a similar adsorption behaviour vs. $\mathrm{pH}$ on an Na-conditioned Silver Hill illite at $\mathrm{I}=0.1 \mathrm{M}\left(\mathrm{NaClO}_{4}\right)$. Missana et al. (2008) - original data in $\mathrm{NaClO}_{4}$ provided by the author - obtained a medium $\log _{10} \mathrm{R}_{\mathrm{D}}$ which is not significantly distinct - ca. 2.1, against ca. 2.0 for Poinssot et al. (1999b) between pH 5 and 8, by considering a $\log _{10} R_{D}$ uncertainty ca. $0.15 \log$ unit. Conversely, it seems that the $\log _{10} \mathrm{R}_{\mathrm{D}}$ obtained at $\mathrm{pH}$ higher than 9 by Missana et al. (2008) were slightly lower than the data from Poinssot et al. (1999b), but close to the ones from Altmann et al. (2015). At I = 0.01 M ( $\left.\mathrm{NaClO}_{4}\right)$ it also seems that values from Poinssot et al. (1999b) and Altmann et al. (2015) are significantly 
lower than the ones obtained by Missana et al. (2008) in neutral $\mathrm{pH}$ range - i.e. $\log _{10} \mathrm{R}_{\mathrm{D}}$ ca. 3.6 for Poinssot et al. (1999b) and ca. 4.3 for Missana et al. (2008). It was decided nevertheless to principally sit our modelling on the data from Poinssot et al. (1999b) and Altmann et al. (2015) in view of the common illite origin. The obtained modelling will nevertheless be compared with the data from Missana et al. (2008).

Fig. 4 shows the adsorption isotherm of $\mathrm{Sr}^{2+}$ vs. pH at $\mathrm{I}=0.1$ (Fig. 4a) and 0.01 (Fig. 4b) $\mathrm{M}$ $\left(\mathrm{NaClO}_{4}\right)$, respectively, and $[\mathrm{Sr}]_{\text {total }}<10^{-9} \mathrm{M}$. At $\mathrm{I}=0.1 \mathrm{M}$, the adsorption is strongly increasing at acidic $\mathrm{pH}$ then is reaching a plateau in the $\mathrm{pH}$ span 5-8. At more alkaline $\mathrm{pH}$, the adsorption is increasing again. At $\mathrm{I}=0.01 \mathrm{M}$, the $\log _{10} \mathrm{R}_{\mathrm{D}}$ raised to a plateau at $\mathrm{pH}$ below 6 (Fig. 4b). These adsorption behaviours are reminiscent of $\mathrm{Sr}^{2+}$ onto Na-smectite (Siroux et al., 2017).

Fig. 5 shows the adsorption isotherm of $\mathrm{Sr}^{2+}$ vs. the equilibrium concentration onto an Na-illite at $\mathrm{pH} 7$ and $\mathrm{I}=0.1 \mathrm{M}\left(\mathrm{NaClO}_{4}\right)$. Here, the adsorption stays constant, i.e. $\log _{10} \mathrm{R}_{\mathrm{D}}=2$, then decreases at the highest concentrations starting from $[\mathrm{Sr}]_{\mathrm{eq}}=10^{-5} \mathrm{M}$. Once again, this adsorption behaviour recalls the Sr one onto Na-smectite (Siroux et al., 2017). Therefore, it is possible to state that $\mathrm{Sr}^{2+}$ has similar adsorption behaviours onto Na-illite and -smectite when it competes with $\mathrm{Na}^{+}$.

The modelling represents well the experimental data except for the $\mathrm{pH}$ isotherm at $\mathrm{I}=$ $0.01 \mathrm{M}$. Actually, the isotherms in Fig. $4 \mathrm{a}$ and Fig. 5 were acquired at the same ionic strength $(0.1 \mathrm{M})$, and weigh heavily on the corrected coefficient values compared to the data from the isotherm at I $=0.01 \mathrm{M}$. Consequently, the modelling outcome overestimates the data of the experiment at $\mathrm{I}=0.01 \mathrm{M}$. The reasons of this overestimation are probably the same that in $\S 3.2 .2 .1$. The obtained $\log _{10} \mathrm{~K}_{\mathrm{Sr}^{2+}, \mathrm{X}_{\mathrm{i}}} / 2 \mathrm{H}^{+}$are reported in Table 3. As supposed in this study, $\log _{10} \mathrm{~K}_{\mathrm{Sr}^{2+} / 2 \mathrm{H}^{+}}$for illite and $\log _{10} \mathrm{~K}_{\mathrm{Sr}^{2+} / 2 \mathrm{H}^{+}}^{*}$ for smectite are similar except for the $\mathrm{X}_{1}$ and $\mathrm{Y}_{1}$ sites. It seems that the $\mathrm{X}_{0}$ site does not have any significant impact in the $\mathrm{Sr}^{2+}$ adsorption modelling, and it was decided not to consider it in a first approximation.

Comparison with data from Missana et al. (2008) is also shown in Fig. 4. As awaited from the similarity of $\log _{10} \mathrm{R}_{\mathrm{D}}$ values in the neutral $\mathrm{pH}$ range, the data from Missana et al. (2008) are well represented by the modelling. One can notice that the $0.01 \mathrm{M} \mathrm{NaClO}_{4} \mathrm{pH}$-isotherm is better described than the data from Poinssot et al. (1999b) and Altmann et al. (2015), which are used to fit the selectivity coefficients. Nevertheless, the agreement between experiments and simulation is clearly less satisfying at extremum $\mathrm{pH}$ values. The reasons behind these differences are not clear and may be a consequence of the clay mineral dissolution as reminded earlier. 


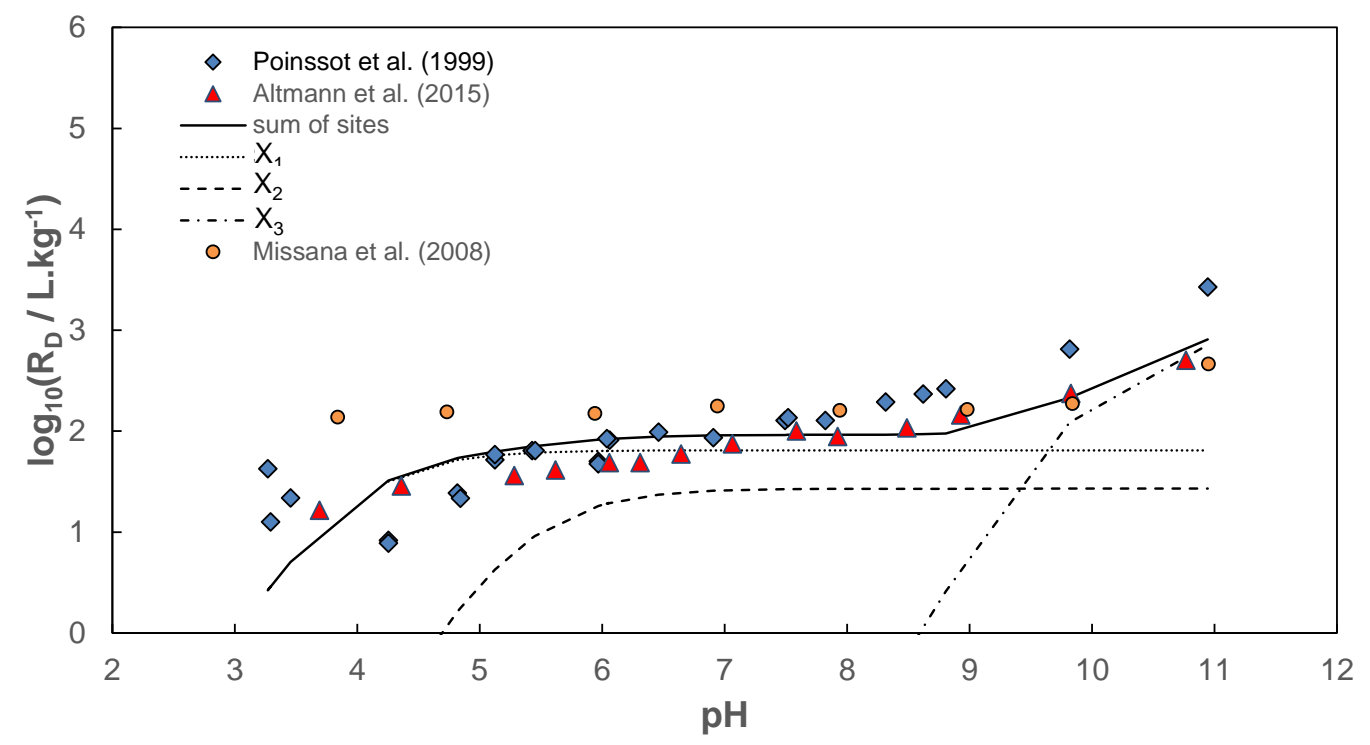

a

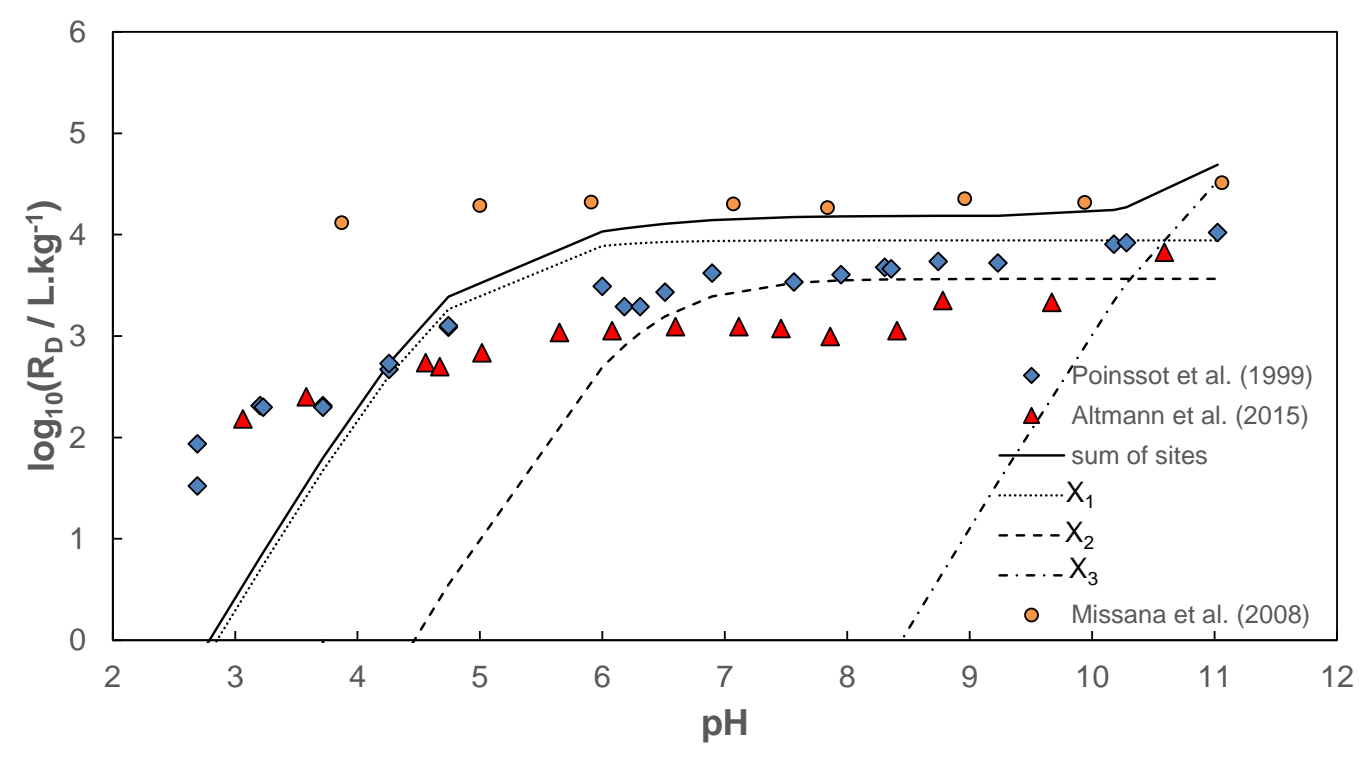

Fig. 4. Adsorption isotherm vs. $\mathrm{pH}$ of $\mathrm{Sr}^{2+}$ onto an $\mathrm{Na}$-illite at $\mathrm{I}=0.1 \mathrm{M}\left(\mathrm{NaClO}_{4}\right)$ (a), and $\mathrm{I}=0.01 \mathrm{M}\left(\mathrm{NaClO}_{4}\right)(\mathrm{b}),[\mathrm{Sr}]_{\text {total }}<10^{-9} \mathrm{M}$ and $\mathrm{S} / \mathrm{L}$ ratio $=1.78 \mathrm{~g} . \mathrm{L}^{-1}$ and modelling with the MSIE formalism. Data digitized from Poinssot et al. (1999b) (diamonds) and Altmann et al. (2015) (triangles), and from Missana et al. (2008) (circles). 

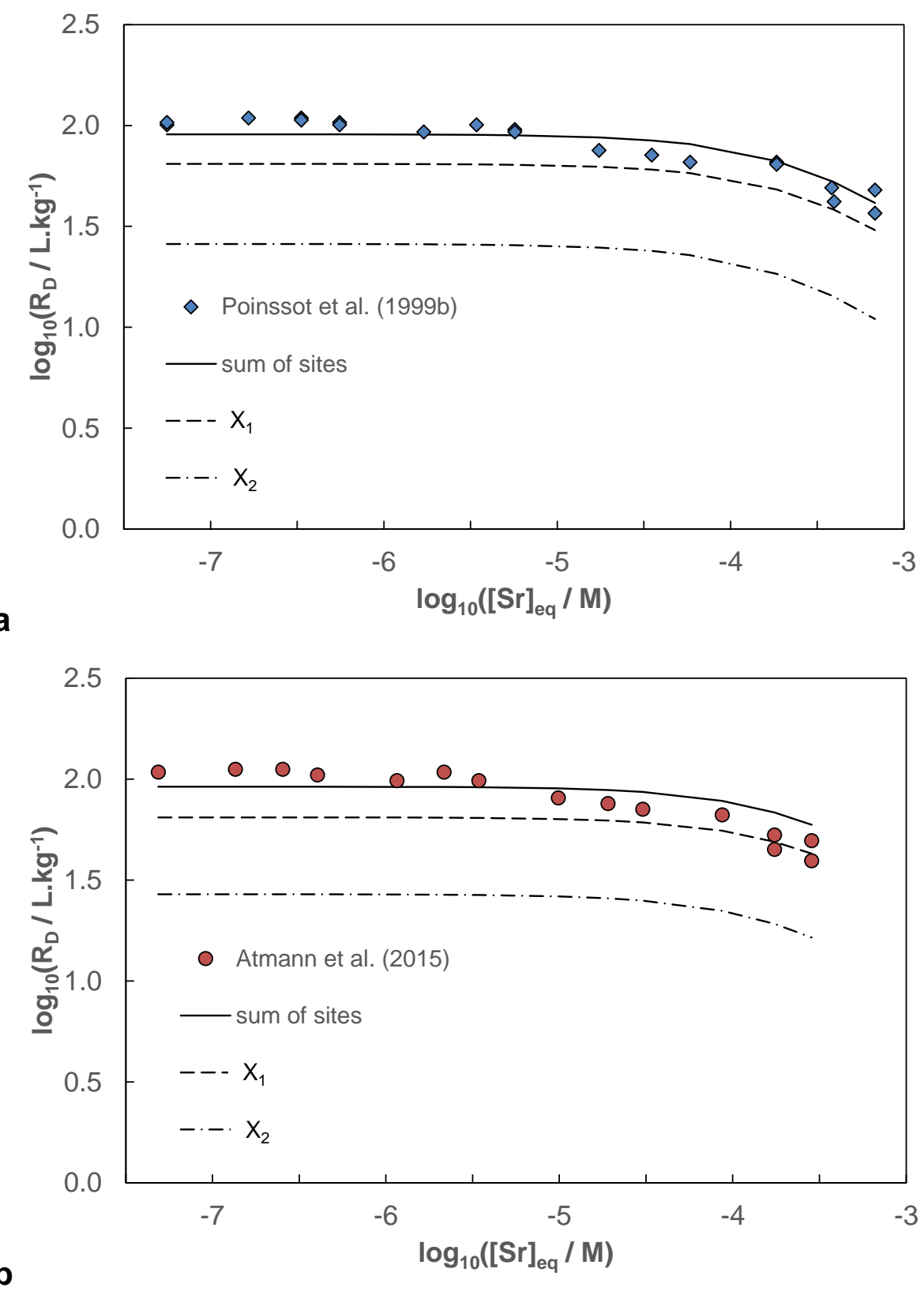

Fig. 5. Adsorption isotherms in concentration of $\mathrm{Sr}^{2+}$ onto an Na-illite at $\mathrm{I}=0.1 \mathrm{M}$ $\left(\mathrm{NaClO}_{4}\right)$, pH 7 (a) and pH 8.3 (b) and S/L ratio = 1.75 g.L.-1 and modelling with the MSIE formalism. Data digitized from (a) Poinssot et al. (1999b) and (b) Altmann et al. (2015). The $X_{3}$ weak contribution to $\log _{10} R_{D}$ at these $p H$ values do not appear in this representation

\subsection{VERIFICATION OF THE ADDITIVITY APPROACH OF THE MSIE MODELLING}

To apply the MSIE modelling with the database in more complex media as soils or sediments, it is possible to apply the additivity approach by combining the relative contribution of each reactive phases in the global adsorption of the mixture. In this study, the additivity approach was used in order to check the efficiency and robustness of this 
database to simulate the adsorption of $\mathrm{Cs}^{+}$and $\mathrm{Sr}^{2+}$ onto illite/smectite mixtures with MSIE formalism. To achieve this aim, adsorption isotherms onto mixtures of pure phases were acquired. Blind simulations were compared to experimental data, by using the $\log _{10} \mathrm{~K}_{\mathrm{M}^{\mathrm{n}+}}^{*, \mathrm{X}_{\mathrm{i}}}$ for illite, and $\log _{10} \mathrm{~K}_{\mathrm{M}^{\mathrm{N}+} / \mathrm{nH}^{+}}^{*}$ for smectite from Siroux et al. (2017) (cf. Table 3).

\subsubsection{Adsorption of $\mathrm{Cs}^{+}$onto $\mathrm{Na}$-illite/Na-smectite mixtures}

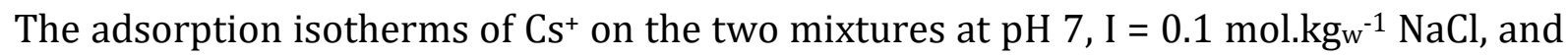
$\mathrm{S} / \mathrm{L}=3.8$ g. $\mathrm{L}^{-1}$ is shown in Fig. 6 . As in $\S 3.2 .2 .1$, the isotherm follows the specific adsorption of $\mathrm{Cs}^{+}$onto illite, which seems to mainly drive the adsorption. Despite the higher percentage of smectite in M1 than in M2, both adsorption behaviours of $\mathrm{Cs}^{+}$onto the mixtures are almost identical. Smectite seems to drive the adsorption at higher total concentration of Cs for M1 - $\log _{10}\left([\mathrm{Cs}]_{\mathrm{eq}} / \mathrm{mol}_{\mathrm{kg}} \mathrm{kg}_{\mathrm{w}}^{-1}\right)>-4-$, and for M2 smectite equals illite contribution only at the highest total Cs concentration $-\log _{10}\left([\mathrm{Cs}]_{\mathrm{eq}} / \mathrm{mol}_{\mathrm{kg}} \mathrm{kg}^{-1}\right) \mathrm{ca}$. -3. The shape of the $\mathrm{Cs}^{+}$adsorption isotherm is well reproduced by the simulation, although experimental results are slightly overestimated at low Cs concentration. This overestimation is especially higher for M2, which contains the higher illite proportion. The origin of these overestimations will be further questioned in the following.

The uncertainty of the simulation can be calculated from the uncertainties on the available parameters in Table 3 using propagation of errors - uncertainties on $\mathrm{X}_{0}$ site capacity and $\log _{10} \mathrm{~K}_{\mathrm{Cs}^{+} / \mathrm{H}^{+}}^{*, \mathrm{X}_{2}}$ for illite are not accounted for. It can be seen (Fig. 6) that at least from the point of view of the fitted parameters uncertainties, the overestimation of the adsorption of $\mathrm{Cs}^{+}$onto the clay minerals mixtures cannot be considered significant. As awaited from values in Table 3, the major contributor to the uncertainty being the selectivity coefficient of the $\mathrm{Na}^{+} / \mathrm{H}^{+}$exchange on the high affinity site of illite $\mathrm{X}_{0}, \log _{10} \mathrm{~K}_{\mathrm{Na}^{+} / \mathrm{H}^{+}}$, at trace concentration of $\mathrm{Cs}^{+}-$affecting a $100 \%$ uncertainty on $\mathrm{X}_{0}$ site capacity and $\log 10 \mathrm{~K}_{\mathrm{Cs}^{+} / \mathrm{H}^{+}}^{*, \mathrm{X}_{2}}$ does not greatly affect the global feature. 

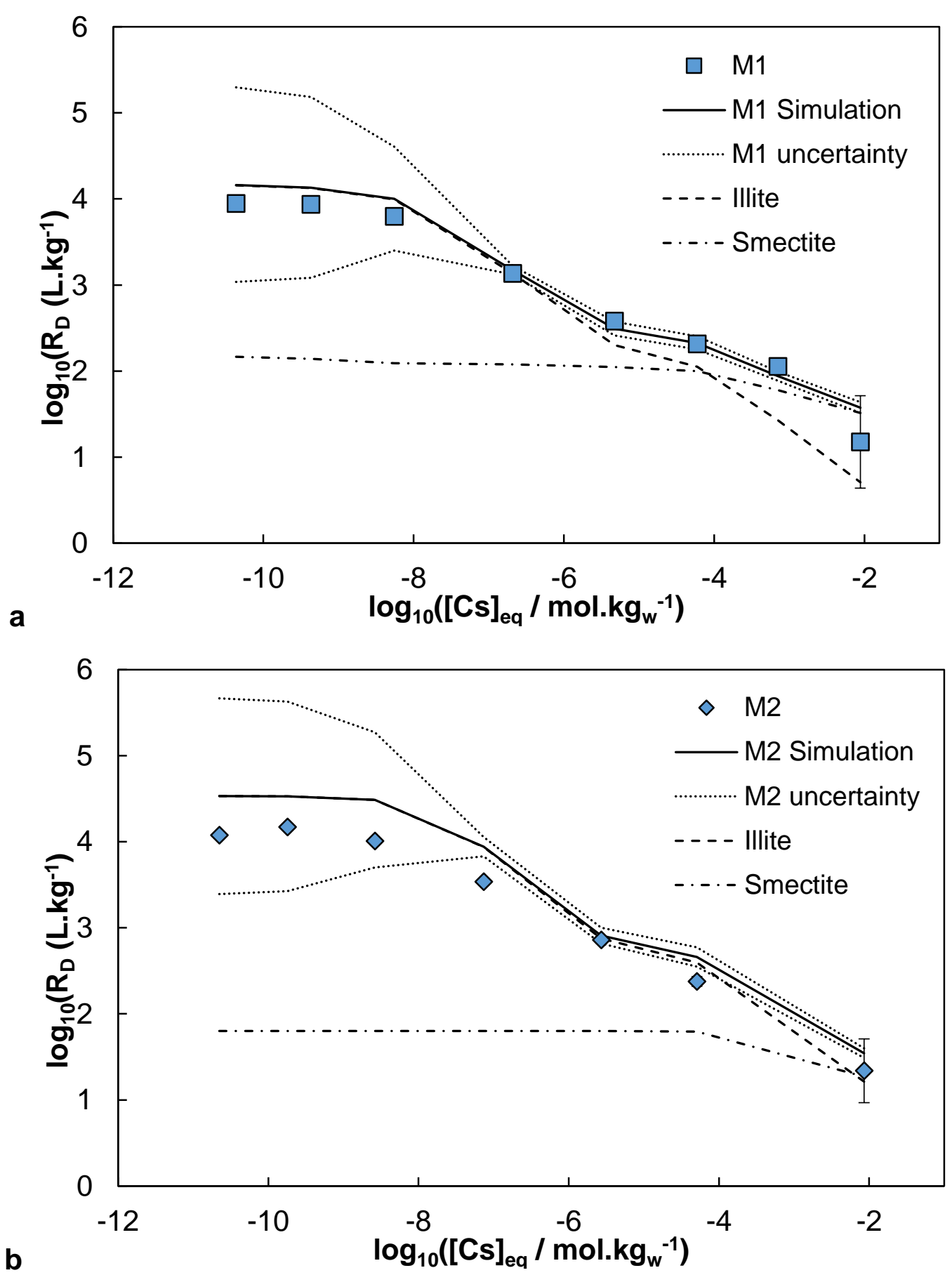

Fig. 6. Adsorption isotherms in equilibrium concentration of Cs at I = 0.1 mol.kg $\mathrm{w}^{-1}$ $(\mathrm{NaCl}), \mathrm{pH}=7$ and $\mathrm{S} / \mathrm{L}$ ratio $=3.8 \mathrm{~g} \cdot \mathrm{L}^{-1}$ on mixture $\mathrm{M} 1$ (a) and $\mathrm{M} 2$ (b) (composition in Table 2) with the associated simulations (plain) and uncertainty $(1 \sigma, d o t)$, compared with illite (dash) and smectite (dash-dot) contributions.

\subsubsection{Adsorption of $\mathrm{Sr}^{2+}$ onto Na-illite/Na-smectite mixtures}

The adsorption isotherms of $\mathrm{Sr}^{2+}$ onto both mixtures are presented in Fig. 7. As discussed in $\S 3.2 .2 .2$, smectite and illite are showing comparable $\mathrm{Sr}^{2+}$ adsorption behaviours, which 
can explain that the obtained $\log _{10} \mathrm{R}_{\mathrm{D}}$ are similar for both mixtures. For $\mathrm{Sr}^{2+}$, the adsorption is both linked to the proportion of each exchanger - i.e., in mixture M1 or M2

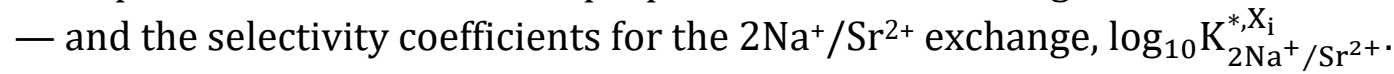

If one considers only the exchange capacity, the adsorption of $\mathrm{Sr}^{2+}$ should be slightly higher in mixtures with higher concentration of smectite. This is shown in Fig. 7, where the adsorption of $\mathrm{Sr}^{2+}$ is slightly higher onto M1 (Fig. 7a) than onto M2 (Fig. 7b) at $\log _{10}\left([\mathrm{Sr}]_{\text {eq }} / \mathrm{mol} \cdot \mathrm{kg}_{\mathrm{w}}{ }^{-1}\right)>-3.3$. However, this seems difficult to assess as the final $\log _{10} \mathrm{R}_{\mathrm{D}}$ values for the two mixtures are almost the same - i.e. $\log _{10} \mathrm{R}_{\mathrm{D}}$ are 2.11 and 2.01 for M1 and M2 mixtures, respectively. Despite a very slight overestimation, in particular for the M2 mixture, the agreement between simulations and experimental results is good. Simulations also follow well the decrease in adsorption caused by the addition of illite. It seems that in the case of $\mathrm{Sr}^{2+}$, the database used allows a correct representation of the adsorption behaviour onto illite/smectite mixtures.

This non-significant difference between M1 and M2 isotherms is coming from the higher selectivity coefficients for the $2 \mathrm{Na}^{+} / \mathrm{Sr}^{2+}$ exchange on Na-illite,

$$
\log _{10} \mathrm{~K}_{2 \mathrm{Na}^{+} / \mathrm{Sr}^{2+}}^{*, \mathrm{X}_{\mathrm{i}}}=2 \log _{10} \mathrm{~K}_{\mathrm{Na}^{+} / \mathrm{H}^{+}}^{*}-\log _{10} \mathrm{~K}_{\mathrm{Sr}^{+} / 2 \mathrm{H}^{+}}^{* \mathrm{X}_{\mathrm{i}}}
$$

the values of which are shown in Table 4 - calculated from Table 3 . The selectivity coefficients for illite are at least an order of magnitude higher than the one for smectite, when the total site capacity is 3.6 times higher for smectite compared to illite. Considering, pure Na-illite (this study) and pure Na-smectite (Siroux et al., 2017), similar $\mathrm{R}_{\mathrm{D}}$ at $0.1 \mathrm{M}$ $\mathrm{NaClO}_{4}$ are observed. Consequently, combining both minerals in various proportions leads to comparable $\mathrm{R}_{\mathrm{D}}$ values.

Table 4. Total site capacities of the clay minerals, and selectivity coefficients for the $2 \mathrm{Na}^{+} / \mathrm{Sr}^{2+}$ exchange calculated using values from Table 3.

\begin{tabular}{cc}
\hline Illite $(24.9 \pm 1.9)$ & mmol.100g-1 \\
\hline $\log _{10} \mathrm{~K}_{2 \mathrm{Na}^{+}}^{*} \mathrm{X}_{1} \mathrm{Sr}^{2+}$ & $1.79 \pm 0.16$ \\
$\log _{10} \mathrm{~K}_{2 \mathrm{Na}^{+} / \mathrm{Sr}^{2+}}$ & $2.38 \pm 0.50$ \\
$\log _{10} \mathrm{~K}_{2 \mathrm{Na}^{+} / \mathrm{Sr}^{2+}}$ & $3.46 \pm 0.38$ \\
\hline \multicolumn{2}{l}{ Smectite $(88.7 \pm 12.1) \mathrm{mmol} .100 \mathrm{~g}^{-1}$} \\
\hline $\log _{10} \mathrm{~K}_{2 \mathrm{Na}^{+} / \mathrm{Sr}^{2+}}^{+}$ & $0.68 \pm 0.08$ \\
$\log _{10} \mathrm{~K}_{2 \mathrm{Na}^{+} / \mathrm{Sr}^{2+}}^{*}$ & $1.00 \pm 0.19$ \\
$\log _{10} \mathrm{~K}_{2 \mathrm{Na}^{+} / \mathrm{Sr}^{2+}}^{*}$ & $2.91 \pm 0.28$ \\
\hline
\end{tabular}

As in the case of $\mathrm{Cs}^{+}$adsorption on the clay minerals mixtures, the uncertainties of the $\mathrm{Sr}^{2+}$ simulations can be calculated by propagation of errors using the values in Table 3 . It can be seen (Fig. 7) that the simulations are not significantly different. Nevertheless, the origin 
of the uncertainties are slightly different. The main contributors to the uncertainty being:

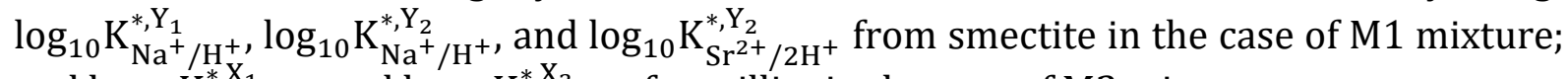
and $\log _{10} \mathrm{~K}_{\mathrm{Na}^{+} / \mathrm{H}^{+}}^{*}$ and $\log _{10} \mathrm{~K}_{\mathrm{Na}^{+} / \mathrm{H}^{+}}^{*, \mathrm{X}_{2}}$ from illite in the case of M2 mixture.

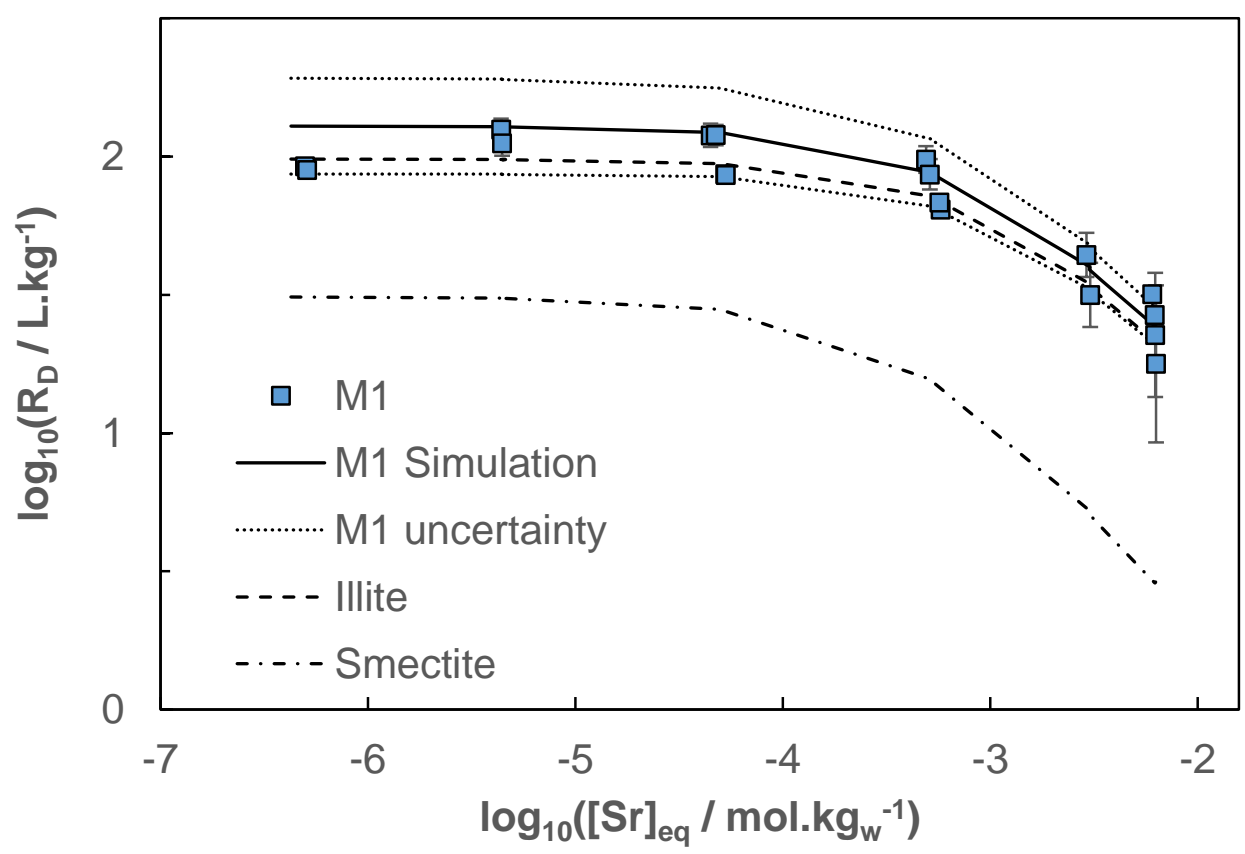

a

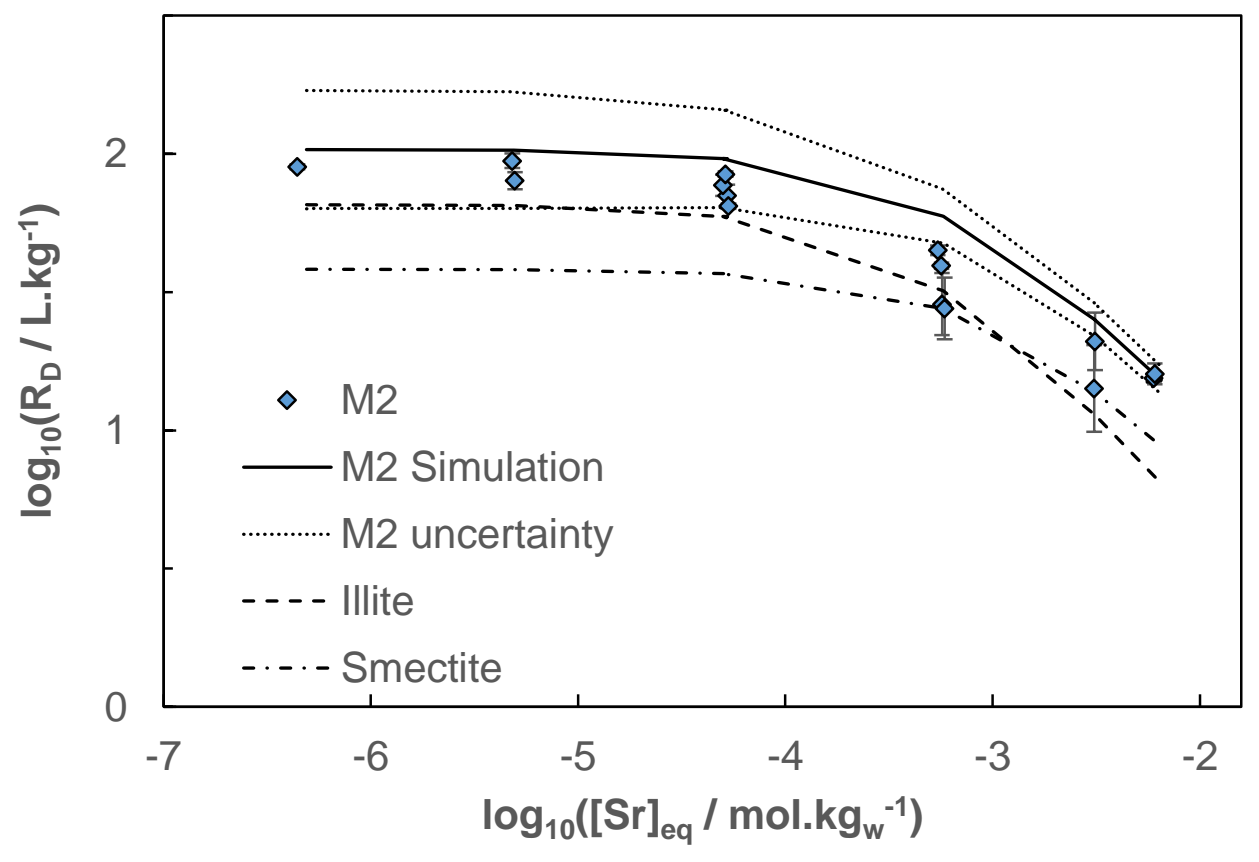

Fig. 7. Adsorption isotherms of $\mathrm{Sr}$ vs. equilibrium concentration at I $=0.1$ mol.kg $\mathrm{kg}_{\mathrm{w}} \mathbf{1}^{-1}$ ( $\mathrm{NaCl}$ ), $\mathrm{pH} 7$ and $\mathrm{S} / \mathrm{L}$ ratio $=3.8{\mathrm{~g} . \mathrm{L}^{-1}}^{-1}$ on $\mathrm{M} 1$ (a) and $\mathrm{M} 2$ (b) - see composition in Table 2 - with the associated simulations (plain) and uncertainty $(1 \sigma, d o t)$, compared with illite (dash) and smectite (dash-dot) components. 


\subsubsection{Discussion on the additivity results}

The measured CEC of the two purified clay minerals used in this study are showing different values compared to those from the database: smectite has a CEC of 88.7 meq.100 g ${ }^{-1}$, against 83.3 meq. $100 \mathrm{~g}^{-1}$ for our SWy-2 smectite, and illite has a CEC of 24.9 meq.100g-1, against 20.9 meq.100g-1 for our illite du Puy. Given the XRD analysis (cf. § 2.1), one can postulate that the used smectite and illite contained impurities. In view of the measured CEC, it is possible to estimate that the smectite and illite are $94 \%$ and $84 \%$ pure, respectively. These impurities produce a lesser impact on the sample CEC than the uncertainty calculated on the total site capacity - cf. Table 3 for smectite $(88.7 \pm 12.1)$

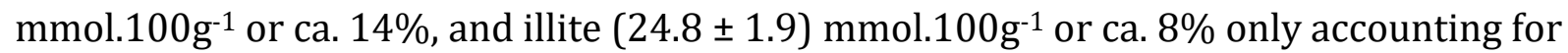
$\mathrm{X}_{1}$ to $\mathrm{X}_{3}$ site. As seen earlier, these differences may be integrated through the uncertainties of the simulations. This impurity rates are accounted for in Fig. 8, implying a lowering of $\log _{10} \mathrm{R}_{\mathrm{D}}$. Although the adsorption of $\mathrm{Cs}^{+}$onto M1 (Fig. 8a) is better represented, the representation of M2 experiment is still slightly overestimated. In the case of $\mathrm{Sr}^{2+}$ (Fig. 8b), the impurity of clay minerals does not significantly change the simulations. In all cases the account of purity is still within the uncertainties of the simulations (vide ante).

The impurity of the clay minerals is not sufficient to explain the slight overestimation of adsorbed Cs onto the clay mixtures. Nevertheless, this problem could come from the clay minerals themselves, especially the illite du Puy. As seen earlier (cf. § 2.1), the purified and Na-conditioned illite du Puy still presents traces of exchangeable $\mathrm{K}^{+}$, i.e. 1.1 meq. $100 \mathrm{~g}^{-1}$, which represents around $5 \%$ of the illite CEC. As $\mathrm{Cs}^{+}, \mathrm{K}^{+}$is well known to interact strongly with illite - especially with the FES - , the presence of $\mathrm{K}^{+}$could interfere with the adsorption of $\mathrm{Cs}^{+}$even at trace concentration. Missana et al. (2014a) showed this effect studying the adsorption of $\mathrm{Cs}^{+}$onto various conditioned illite. Onto K-illite the adsorption of $\mathrm{Cs}^{+}$was shown to be lower than onto Na-illite - a decrease of around 2.2 units of $\log \mathrm{R}_{\mathrm{D}}$ was observed at low Cs concentration. 


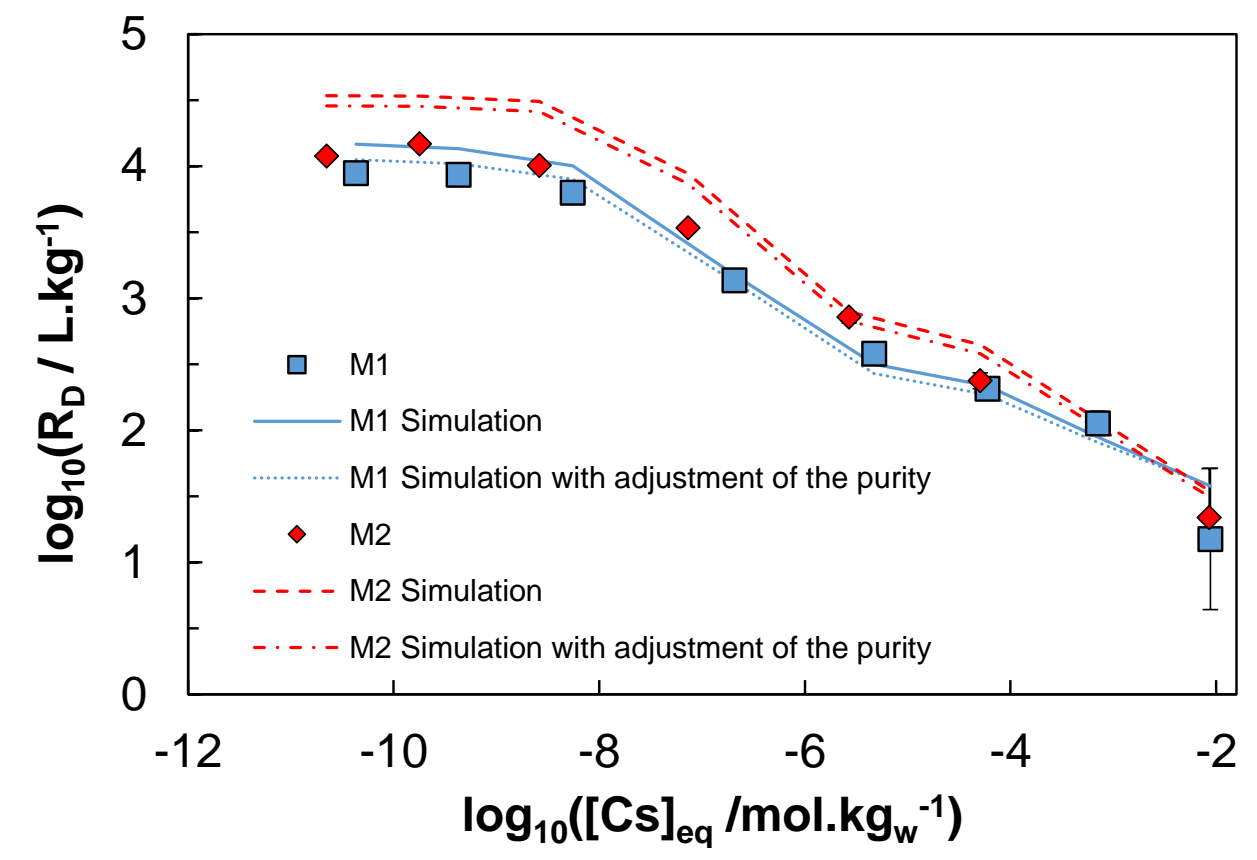

a

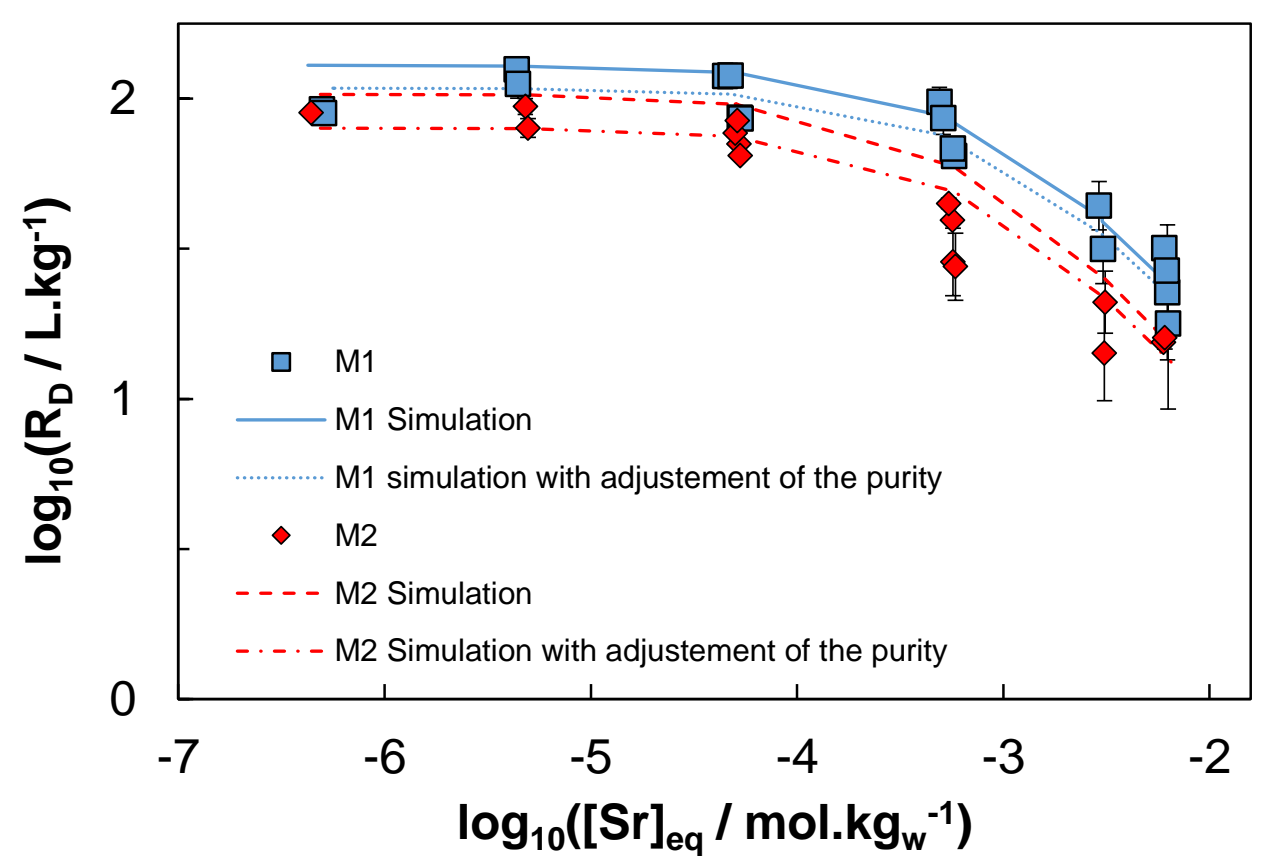

Fig. 8. Adsorption isotherms vs. equilibrium concentration of Cs (a) and $\mathrm{Sr}$ (b) at $\mathrm{I}=0.1 \mathrm{~mol} . \mathrm{kgw}^{-1}(\mathrm{NaCl}), \mathrm{pH} 7$ and $\mathrm{S} / \mathrm{L}$ ratio $=3.8 \mathrm{~g} \cdot \mathrm{L}^{-1}$ on mixture M1 (squares) and M2 (diamonds) (composition in Table 2); the associated simulations for M1 in Fig. 6 (plain) and M2 in Fig. 7 (dash) are compared to the simulation taking into account of the clay minerals purity for M1 (dot) and M2 (dash-dot). 


\subsubsection{Discussions on the limitations and advantages of the MSIE modelling}

Several limitations are to be considered for this kind of modelling exercise. As already emphasized, applying selectivity coefficients that are fitted even at different ionic strengths to whatever ionic strength could be a problem if the strong hypothesis of the constant ratio of the activity coefficient of adsorbed species is not verified. The same applies if the change in ionic strength is inducing structural modification within the clay minerals. Considering that an illite or a smectite from sedimentary locations, from a soil, or even synthetic clays, are showing the same adsorption properties is also a strong hypothesis, which can induce caution in the outcome of the modelling.

The parameters can be applied in various conditions. First, it applies in wide ranges of physico-chemical parameters, i.e. ionic strength and $\mathrm{pH}$, which ensures its applicability in various contexts. Second, it is applicable at various mass upon volume ratios, which ensures its applicability in reactive transport in porous media. Finally, any competition adsorption reaction, or side reaction in solution, can be taken into account as long as the selectivity coefficient, or thermodynamic constant, are available.

\section{CONCLUSIONS}

The adsorption of $\mathrm{Cs}^{+}$and $\mathrm{Sr}^{2+}$ onto a purified Na-illite has been studied and compiled from the literature. These isotherms were modelled within the MSIE formalism with the aim of obtaining corrected selectivity coefficients for the $\mathrm{Na}^{+} / \mathrm{H}^{+}, \mathrm{Cs}^{+} / \mathrm{H}^{+}$, and $\mathrm{Sr}^{2+} / 2 \mathrm{H}^{+}$ ion-exchange reactions $-\mathrm{Na}^{+} / \mathrm{Cs}^{+}$and $\mathrm{Sr}^{2+} / 2 \mathrm{Na}^{+}$can be calculated from these values. The experiments are generally well represented by the modelling. These representations assure a good efficiency and robustness of the obtained database to simulate the adsorption of $\mathrm{Cs}^{+}$and $\mathrm{Sr}^{2+}$ onto Na-illite.

Afterwards, the performance of the modelling and the database, including the parameters from Siroux et al. (2017), was verified onto illite/smectite mixtures. Despite overestimations observed at low Cs concentration, the good agreement between the experimental isotherms of the adsorption of $\mathrm{Cs}^{+}$and $\mathrm{Sr}^{2+}$ with the simulations tends to confirm the robustness of the database, which could be used to predict the adsorption behaviour of $\mathrm{Cs}^{+}$and $\mathrm{Sr}^{2+}$ onto more complex phases as sediments or soils.

\section{ACKNOWLEDGMENTS}

This work was financed through the French "Programme Investissement d'Avenir" (ANR11-RSNR-0005 DEMETERRES). Orano (then-Areva) is acknowledged for its financial support. Dr. Tiziana Missana is acknowledged for providing original data on $\mathrm{Sr}^{2+}$ adsorption onto illite. 


\section{REFERENCES}

Altmann, S., Aertsens, M., Appelo, T., Bruggeman, C., Gaboreau, S., Glaus, M., Jacquier, P., Kupcik, T., Maes, N., Montoya, V., Rabung, T., Robinet, J.-C., Savoye, S., Schäfer, T., Tournassat, C., Van Laer, L., Van Loon, L., 2015, Processes of Cation Migration in Clayrocks: Final Scientific Report of the CatClay EuropeanProject. CEA, Gif-surYvette, France. Report CEA-R-6410 (ISSN 04293460). http://hal-cea.archives-ouvertes.fr/cea01223753. Last Accessed 19 March 2018.

Amram, K., Ganor, J., 2005. The combined effect of $\mathrm{pH}$ and temperature on smectite dissolution rate under acidic conditions. Geochim.

Cosmochim. Acta 69, 2535-2546.

http://doi.org/10.1016/j.gca.2004.10.001.

Bradbury, M.H., Baeyens, B., 1997. A mechanistic description of $\mathrm{Ni}$ and $\mathrm{Zn}$ sorption on $\mathrm{Na}$ montmorillonite. Part II: modelling. J. Contam. Hydrol. 27, 223-248. http://doi.org/10.1016/S0169-7722(97)000077.

Bradbury, M.H., Baeyens, B., 1999. Modelling the sorption of $\mathrm{Zn}$ and $\mathrm{Ni}$ on Ca-montmorillonite. Geochim. Cosmochim. Acta 63, 325-336. http://doi.org/10.1016/S0016-7037(98)002816.

Bradbury, M.H., Baeyens, B., 2005, Experimental and Modelling Investigations on Na-Illite: AcidBase Behaviour and the Sorption of Strontium, Nickel, Europium and Uranyl. Paul Scherrer Institut, Villigen, Switzerland. Report PSI 05-02 and Nagra NTB 04-02. pp. 73.

http://www.nagra.ch/data/documents/databas e/dokumente/\$default/Default\%20Folder/Publ ikationen/NTBs\%202001-2010/e ntb04-02.pdf. Last Accessed 19 March 2018.
Brouwer, E., Baeyens, B., Maes, A., Cremers, A., 1983. Cesium and rubidium ion equilibria in illite clay. J. Phys. Chem. 87, 1213-1219. http://doi.org/10.1021/j100230a024.

Chen, X., Peng, S.C., Wang, J., 2015. Retention profile and kinetics characteristics of the radionuclide $90-\mathrm{Sr}(\mathrm{II})$ onto kaolinite. J. Radioanal. Nucl. Chem. 303, 509-519. http://doi.org/10.1007/s10967-014-3458-6.

Cremers, A., Elsen, A., Depreter, P., Maes, A., 1988. Quantitative analysis of radiocaesium retention in soils. Nature 335, 247-249. http://doi.org/10.1038/335247a0.

Davies, C.W., 1962. Ion association.

Butterworths, Washington, DC, USA. pp. 190.

De Levie, R., 2004. Advanced Excel for Scientific Data Analysis. Oxford University Press, Oxford, UK. pp. 638.

Dzene, L., Tertre, E., Hubert, F., Ferrage, E., 2015. Nature of the sites involved in the process of cesium desorption from vermiculite. J. Colloid Interface Sci. 455, 254-260.

http://doi.org/10.1016/j.jcis.2015.05.053.

England, T.R., Rider, B.F., 1993, ENDF-349

Evaluation and Compilation of Fission Product

Yields. Lawrence Berkeley National Laboratory, Berkeley, CA, USA. Report LA-UR-3106. pp. 173. http://t2.lanl.gov/nis/publications/endf349.pdf. Last Accessed 19 March 2018.

Erten, H.N., Aksoyoglu, S., Hatipoglu, S., Gokturk, H., 1988. Sorption of cesium and strontium on montmorillonite and kaolinite. Radiochim. Acta 44/45, 147-151.

http://doi.org/10.1524/ract.1988.4445.1.147. 
Fuller, A.J., Shaw, S., Ward, M.B., Haigh, S.J., Mosselmans, J.F.W., Peacock, C.L., Stackhouse, S., Dent, A.J., Trivedi, D., Burke, I.T., 2015. Caesium incorporation and retention in illite interlayers. Appl. Clay Sci. 108, 128-134.

http://doi.org/10.1016/j.clay.2015.02.008.

Gailhanou, H., Blanc, P., Rogez, J., Mikaelian, G., Kawaji, H., Olives, J., Amouric, M., Denoyel, R., Bourrelly, S., Montouillout, V., Vieillard, P., Fialips, C.I., Michau, N., Gaucher, E.C., 2012. Thermodynamic properties of illite, smectite and beidellite by calorimetric methods: enthalpies of formation, heat capacities, entropies and Gibbs free energies of formation. Geochim. Cosmochim. Acta 89, 279-301.

http://doi.org/10.1016/j.gca.2012.04.048.

Gailhanou, H., Vieillard, P., Blanc, P., Lassin, A., Denoyel, R., Bloch, E., De Weireld, G., Gaboreau, S., Fialips, C.I., Made, B., Giffaut, E., 2017. Methodology for determining the thermodynamic properties of smectite hydration. Appl. Geochem. 82, 146-163. http://doi.org/10.1016/j.apgeochem.2017.04.0 $\underline{15}$.

Galamboš, M., Krajnak, A., Rosskopfová, O., Viglasova, E., Adamcova, R., Rajec, P., 2013. Adsorption equilibrium and kinetic studies of strontium on Mg-bentonite, Fe-bentonite and illite/smectite. J. Radioanal. Nucl. Chem. 298, 1031-1040. http://doi.org/10.1007/s10967013-2511-1.

Gaucher, E., 1998. Interactions eaux-argiles. Etude expérimentale. PhD Thesis. Université Denis Diderot (Paris VII), Paris, France. pp. 260. In French.
Gorgeon, L., 1994. Contribution à la modélisation physico-chimique de la rétention de radioéléments à vie longue par des matériaux argileux. PhD Thesis. Université Pierre et Marie Curie (Paris VI), Paris, France. pp. 189. In French. Jacquier, P., Ly, J., Beaucaire, C., 2004. The ionexchange properties of the Tournemire argillite: I. Study of the H, Na, K, Cs, Ca and Mg behaviour. Appl. Clay Sci. 26, 163-170.

http://doi.org/10.1016/j.clay.2003.09.009.

Long, H., Wu, P., Yang, L., Huang, Z., Zhu, N., Hu, Z., 2014. Efficient removal of cesium from aqueous solution with vermiculite of enhanced adsorption property through surface modification by ethylamine. J. Colloid Interface Sci. 428, 295-301.

http://doi.org/10.1016/j.jcis.2014.05.001.

Ly, J., Stammose, D., Pitsch, H., 1991. Description of actinides sorption onto clays by ion-exchange mechanism, Migration'91, Jerez de la Frontera, Spain.

Mahoney, J.J., Langmuir, D., 1991. Adsorption of Sr on kaolinite, illite and montmorillonite at high ionic strengths. Radiochim. Acta 54, 139-144. http://doi.org/10.1524/ract.1991.54.3.139.

Missana, T., García-Gutiérrez, M., Alonso, U., 2008. Sorption of strontium onto illite/smectite mixed clays. Phys. Chem. Earth 33, S156-S162. http://doi.org/10.1016/i.pce.2008.10.020.

Missana, T., Benedicto, A., Garcia-Gutierrez, M., Alonso, U., 2014a. Modeling cesium retention onto Na-, K- and Ca-smectite: effects of ionic strength, exchange and competing cations on the determination of selectivity coefficients. Geochim. Cosmochim. Acta 128, 266-277. http://doi.org/10.1016/i.gca.2013.10.007. 
Missana, T., García-Gutiérrez, M., Benedicto, A., Ayora, C., De-Pourcq, K., 2014b. Modelling of Cs sorption in natural mixed-clays and the effects of ion competition. Appl. Geochem. 49, 95-102. http://doi.org/10.1016/j.apgeochem.2014.06.0 $\underline{11}$.

Montavon, G., Alhajji, E., Grambow, B., 2006. Study of the interaction of $\mathrm{Ni}^{2+}$ and $\mathrm{Cs}^{+}$on $\mathrm{MX}-80$ bentonite; effect of compaction using the "capillary method". Environ. Sci. Technol. 40, 4672-4679. http://doi.org/10.1021/es052483i.

Motellier, S., Ly, J., Gorgeon, L., Charles, Y., Hainos, D., Meier, P., Page, J., 2003. Modelling of the ion-exchange properties and indirect determination of the interstitial water composition of an argillaceous rock. Application to the Callovo-Oxfordian low-water-content formation. Appl. Geochem. 18, 1517-1530. http://doi.org/10.1016/s0883-2927(03)00049$\underline{0}$.

Nie, Z., Finck, N., Heberling, F., Pruessmann, T., Liu, C., Lützenkirchen, J., 2017. Adsorption of selenium and strontium on goethite: EXAFS study and surface complexation modeling of the ternary systems. Environ. Sci. Technol. 51, 37513758. http://doi.org/10.1021/acs.est.6b06104.

Novotny, P., Sohnel, O., 1988. Densities of binary aqueous solutions of 306 inorganic substances. J. Chem. Eng. Data 33, 49-55. http://doi.org/10.1021/je00051a018.

Peynet, V., 2003. Retention d'actinide et de produits de fission par des phases solides polyminerales. PhD Thesis. Université Pierre et Marie Curie (Paris VI), Paris, France. pp. 273. In French.
Poinssot, C., Baeyens, B., Bradbury, M.H., 1999a. Experimental and modelling studies of caesium sorption on illite. Geochim. Cosmochim. Acta 63, 3217-3227. http://doi.org/10.1016/s00167037(99)00246-x.

Poinssot, C., Baeyens, B., Bradbury, M.H., 1999b, Experimental studies of $\mathrm{Cs}, \mathrm{Sr}, \mathrm{Ni}$ and $\mathrm{Eu}$ sorption on Na-illite and the modelling of Cs sorption. Nagra, Wettingen, Switzerland. Report NTB 99-04. pp. 75.

http://www.nagra.ch/data/documents/databas e/dokumente/\%24default/Default\%20Folder/P ublikationen/NTBs\%201994-2000/e ntb99-

04.pdf. Last Accessed 19 March 2018.

Reinoso-Maset, E., Ly, J., 2014. Study of major ions sorption equilibria to characterize the ion exchange properties of kaolinite. J. Chem. Eng. Data 59, 4000-4009. http://doi.org/10.1021/je5005438.

Robin, V., Tertre, E., Beaufort, D., Regnault, O., Sardini, P., Descostes, M., 2015. Ion exchange reactions of major inorganic cations $\left(\mathrm{H}^{+}, \mathrm{Na}^{+}\right.$, $\mathrm{Ca}^{2+}, \mathrm{Mg}^{2+}$ and $\mathrm{K}^{+}$) on beidellite: experimental results and new thermodynamic database. Toward a better prediction of contaminant mobility in natural environments. Appl. Geochem. 59, 74-84.

http://doi.org/10.1016/j.apgeochem.2015.03.0 16.

Savoye, S., Beaucaire, C., Fayette, A., Herbette, M., Coelho, D., 2012. Mobility of cesium through the Callovo-Oxfordian claystones under partially saturated conditions. Environ. Sci. Technol. 46, 2633-2641. http://doi.org/10.1021/es2037433. 
Savoye, S., Beaucaire, C., Grenut, B., Fayette, A., 2015. Impact of the solution ionic strength on strontium diffusion through the Callovo-

Oxfordian clayrocks: an experimental and modeling study. Appl. Geochem. 61, 41-52.

http://doi.org/10.1016/j.apgeochem.2015.05.0 $\underline{11}$

Sawhney, B.L., 1972. Selective sorption and fixation of cations by clay minerals: a review. Clays Clay Miner. 20, 93-100.

http://doi.org/10.1346/ccmn.1972.0200208.

Siroux, B., Beaucaire, C., Tabarant, M., Benedetti, M.F., Reiller, P.E., 2017. Adsorption of strontium and caesium onto an Na-MX80 bentonite: experiments and building of a coherent thermodynamic modelling. Appl. Geochem. 87, 167-175.

http://doi.org/10.1016/j.apgeochem.2017.10.0 $\underline{22}$.

Stammose, D., Ly, J., Pitsch, H., Dolo, J.M., 1992. Sorption mechanisms of three actinides on a clayey mineral. Appl. Clay Sci. 7, 225-238. http://doi.org/10.1016/0169-1317(92)90041$\underline{\mathrm{K}}$.
Tertre, E., Beaucaire, C., Coreau, N., Juery, A., 2009. Modelling Zn(II) sorption onto clayey sediments using a multi-site ion-exchange model. Appl. Geochem. 24, 1852-1861. http://doi.org/10.1016/j.apgeochem.2009.06.0 $\underline{06}$.

WinDig, 1996, WinDig Data digitizer, http://www.unige.ch/sciences/chifi/cpb/windi g.html, last accessed 19 March 2018.

Wissocq, A., Beaucaire, C., Latrille, C., 2018. Application of the multi-site ion exchanger model to the sorption of Sr and Cs on natural clayey sandstone. Appl. Geochem. 93, 167-177. http://doi.org/10.1016/j.apgeochem.2017.12.0 10.

Zaunbrecher, L.K., Cygan, R.T., Elliott, W.C., 2015. Molecular models of cesium and rubidium adsorption on weathered micaceous minerals. J. Phys. Chem. A 119, 5691-5700.

http://doi.org/10.1021/jp512824k. 